

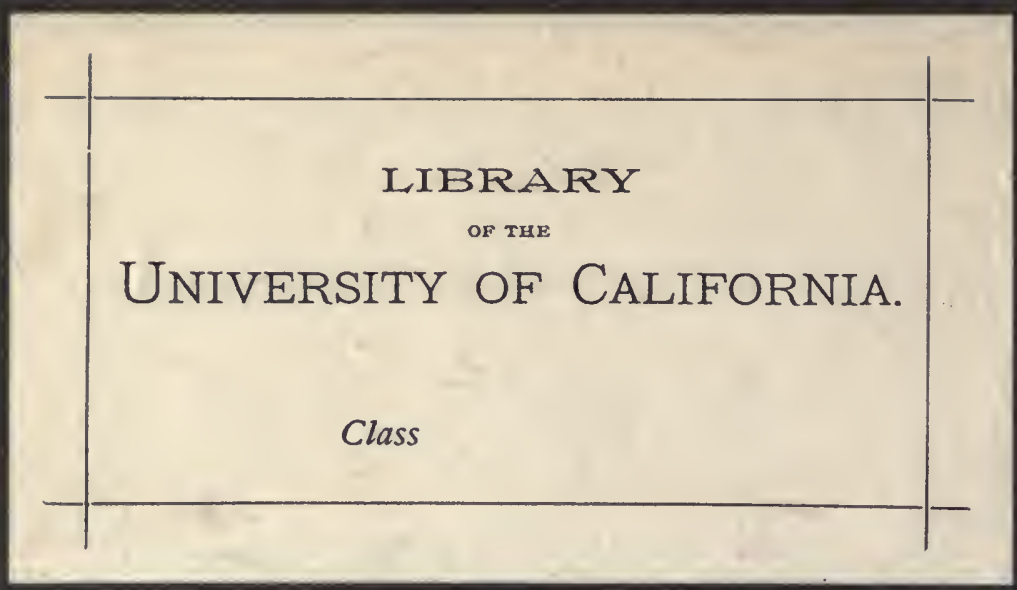


I

\section{Farn}





\title{
FARM ACCOUNTING
}

\section{$\longrightarrow$ For-}

The PRACTICAL FARMER

\author{
$-\mathrm{BY}-$ \\ LLOYD E. GOODYEAR
}

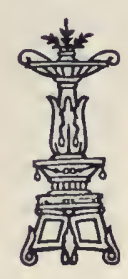




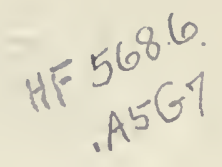

LIBRARIAN'S FURD

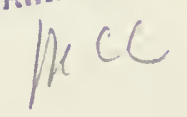

Copyright, 1911.

Goodyear-Marghall Publishing Company.

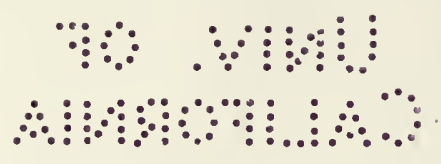




\section{Farm Accounting.}

The farm is a factory in which thought, money, and labor are applied to soil and natural forces in order to combine them into produce for consumption. So long has mankind been engaged in farming that many of its processes can be followed by persons with very little conscious learning, and with no account keeping, just as in former times, it was easy to secure game with a simple bow and arrow. The fact that a certain amount of farming success can be attained without bookkeeping, has made the farm the one kind of factory where bookkeeping has not in the past been universally deemed necessary. Other factories, unless quite small, can no longer run successfully without careful attention to accounts. The larger the establishement the greater the need of bookkeeping, until we reach the great iron works, wood works, machinery works, clothing works, etc., 'where, if the books were not kept for a single day, confusion would reign, and where if books were not kept for a single month, dissolution would set in.

At the present time, we are beginning to witness the coming of men skilled in accounting, who have applied their skill to the farm with the result that large farm chains are being organized, replacing the many small farms which are not safeguarded by a scientific system of accounting. Those who think clearly cannot fail to see that a proper accounting system reduces the labor and mental strain of the prosperous farmer, while the farmer who is still struggling with large payments and small income, must depend on account keeping until his books have guided him to at least a comfortable degree of success. One must get the account keeping attitude now-a-days, if he would master his business.

The stories of the successes of our forefathers in subduing the ivilderness with their vast physical energy, like the stories of knighthood in the middle ages, should contribute the qualities of heroism and chivalry to the sons. But the sons cannot make any eminent success in business today unless they add to their forefathers' vigor, the incisive judgment and adaptability to surroundings demanded by present commercial development. The modern guide to success is the intelligently kept ledger; the modern consultation room is the bookkeeper's desk. The proper study of accounts will do much to restore to the farmer the primary standing which has been usurped by other, masters of business where bookkeeping is more highly specialized.

This set may be classed as belonging to advanced accounting in the sense that it is a complete scientific scheme of accounting equal in grade with that used by the banker. or merchant. In operation it is simple and should not, on an ordinary farm, require more than five or ten minutes per day for its successful use. The principles given are to be thoroughly mastered but when once mastered they should be adequate to future needs.

We hope to see in time to come the evidences of well kept books in the material prosperity of the thousands of farms that adorn the thorofares East, West, North, and South. 


\section{PREPARATION}

It is assumed at the outset that the student is familiar with ordinary business papers and legal forms. Among these are included the note, check, draft, receipt, bill or invoice, bank book, deposit ticket, statement of account, duplicate order and other carbon duplications, letter, envelope, R. R. bill of lading, R. R. expense bill, stock certificate, telegram, C. O. D. form, lease, common agreement, bill of sale, deed, mortgage, release of mortgage, insurance policy, proof of loss, etc. There are few, if any, general business forms that will require particular attention in a study of this kind.

In bookkeeping the student is expected to know the double entry principle and to use it in the common books of original entry, together with posting, trial balance and financial statement. It is desirable that he be able to introduce special columns where needed. Some review in the methods of transferring department statistics to general accounts would also be in order. These matters can be gathered from the general treatment in this set but its practical value would be enhanced if the attention is not diverted from the problem actually in hand.

\section{OBJECT}

The objects to be emphasized in this set are (1) an exhibit of the cost of producing each of the farm products, (2) the returns derived from their sale or use, (3) the general value and progress of the business. These facts should be placed in such form as to render convenient comparison from year to year.

\section{THE LEDGER}

This book is divided into two parts - the first, for general accounts, including an account with each department of farm industry considered; the second, including accounts with notes and persons. It should be a book large enough and well enough bound to last on an ordinary farm for a period of ten years. The standard double entry ledger ruling is used, as the explanation column in it allows room for the memoranda that should accompany practically all entries.

\section{TRIAL BALANCE BOOK}

A continuous trial balance (one with titles to the left and several sets of debit and credit columns for successive trial balances to the right) is used, in which are recorded the trial balances taken on opening the books and thereafter on the last date of each month.

\section{JOURNAL}

A six-column journal is used for all current entries. This book has special debit and credit columns for cash receipts and payments, also merchandise cost and returns. (It will be noted that the Merchandise account represents all finished product in marketable condition.) The journal also holds the distribution of labor, team use, and product. These items are summarized monthly and charged or credited through the journal to the departments affected.

\section{SUMMARY BOOKS}

The essential summary books are three in number: One having columns each for every department requiring manual labor, called the Labor Summary; one having columns for the departments requiring the use of teams, called Team Use Summary; and one having columnns for each division of production having regular output, called Product Summary. Each of these books has a miscellaneous column for entries of unusual labor service, team service, or source of product.

The distribution of above essentials is made daily in the summary books. The daily items are footed monthly and carried to the ledger accounts affected as above explained.

The sales summary may be used for original entrics like the other summary books, if sales are active as they would probably be when garden truck is scld. Ii stich case, sales on account can be posted from the sales summary without entry in the journal, except in toials at the close of the month. 


\section{AUXILIARY BOOKS}

In addition to the above summary books, a number of books for reference not necessary to the accounting scheme may be kept. These are called auxiliary (helping) books, and may be taken up or discontinued as serves the purpose. Among these may be mentioned registers of stock pedigree, records of detailed cost and production in any experimental test, summary of sales for the month showing quantity of each commodity, with prices, etc. Such books, while valuable for the purposes intended, are independent of the accounting scheme.

\section{DAILY REPORT CARDS}

Success in keeping farm books depends on convenience in making the original records. This is brought about by the use of indiviclual report cards properly ruled and printed to accommodate the required clata. Each person working about the place receives a card in the morning in which he fills during the day the time spent in departments, the team use, the product passing through his hands, and on the reverse side of the card the business dealings which he carries out. This card he returns at night together with any cash or other matter that should accompany it. Entries are made from these cards at the convenience of the bookkeeper.who then files them as vouchers.

\section{PRELIMINARY EXERCISE}

\section{DETAILED RECORD FOR EXPERIMENTAL PURPOSES}

The Poultry Record for experimental purposes is here given. A similar record can be kept if desired for any specific line of production. A detailed orchard record, a garden record, a real estate record, etc., would be of value in correcting the uncertainties of "guessing."

The experimental poultry record here given exhibits in detail five items of cost: labor, (2) feed, (3) housing, ground and tools, (4) stock, (5) miscellaneous. It gives three items of production: (1) eggs,.(2) stock, (3) miscellaneous. The columns are lettered A to $\mathrm{H}$ in order to allow a special memorandum to refer to an amount in any column without requiring the use of more than one line per day. Other facts are recorded as shown by the column headings. Notice particularly that the total value of the investment is entered at top and is changed with each day's entries, and at the end of the month, the interest on the investment can be easily computed and charged in.

\section{OPENING THE RECORD}

The inventories at starting should be placed at the head of the columns (red ink) so that the current entries following (black ink) can be footed separately. The red ink amounts at top plus the footings for the current month will be added and carried to the top of the next open folio representing the following month. These in turn will be carried forward month by month to Dec. 31 , the close of the year, when a new register is to be opened for the ensuing year.

\section{MEMORANDA}

The following entries are made on the assumption that the labor is worth $25 \mathrm{c}$ per hour, and that money is worth 6 per cent interest annually. Make all daily calculations correct to the nearest cent.

Dec. 1. Began poultry record today with the following property invested: 120 chickens, 360 lb.@10c per 1b., entered in column D; Chicken house valued@ \$84.50, fencing, crates, etc., $\$ 16.80$, bone grinder, $\$ 7.50$, sprayer, $\$ 3.00$, in column $\mathrm{C} ; 40 \mathrm{lb}$. chick feed worth 80 cts., 12 bu. corn@ @ 50 cts., 7 bu. wheat@ @1.10, in column B; one Poultry Guide Book, $\$ 1.20$, unexpired subscription to the Poultry Journal, 40c, in column E.

\footnotetext{
Enter number of poultry on hand in column provided for that purpose. Enter the values here shown in the respective debit columns (red ink). Enter the total in the investment balance column (black ink). In this exercise, entries are to be made directly into the record from memoranda as given.
} 


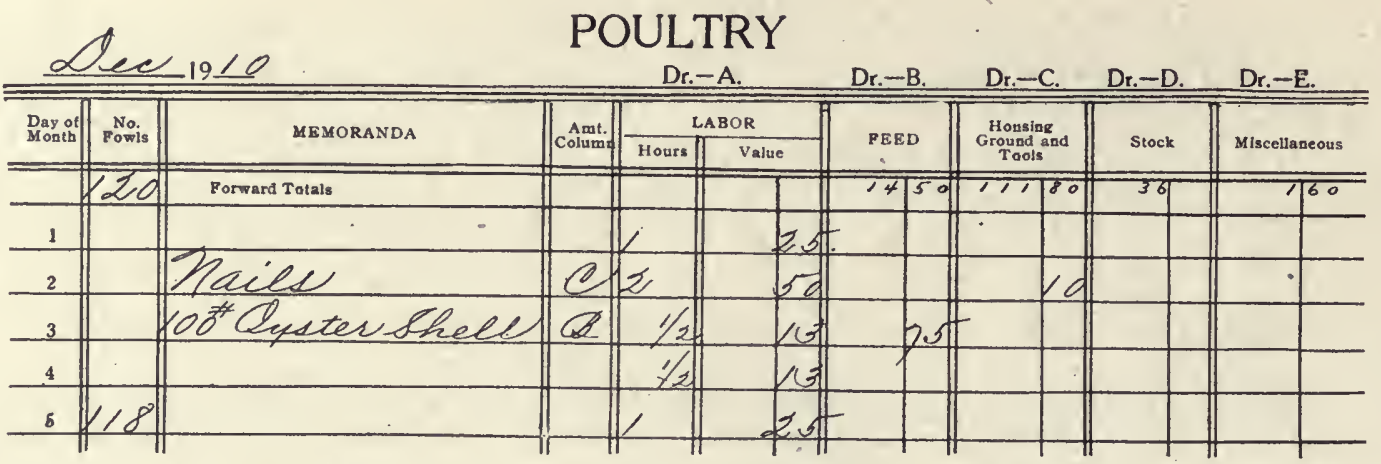

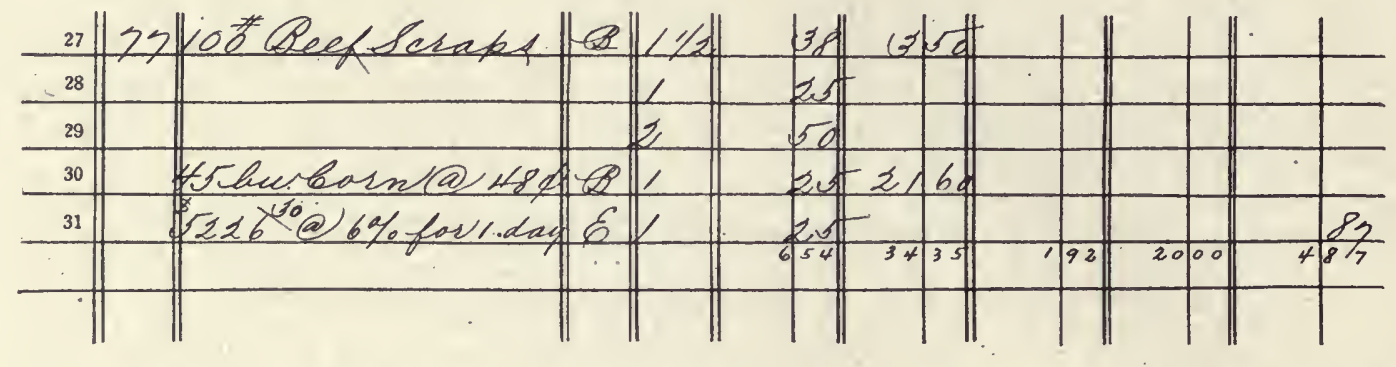

Dec. 1. During the day, one hour was spent in labor on poultry and 17 eggs worth 24 cts. per doz. were gathered. Charge labor 25 cts., and credit eggs 34 cts. on the line dated Dec. 1.

Add the debit and subtract the credit from the investment balance showing the investment burden reduced to $\$ 163.81$.

Dec. 2. Today, spent time 2 hrs.; nails purchased 10c; eggs gathered $16 @ 24 \mathrm{c}$ Enter and extend balance.

Note that the explanation referring to the nails purchased refers to the entry for the amount in Column "C"-Housing, Ground and Tools.

Dec. 3. Labor I/2 hour; bought $100 \mathrm{lb}$. oyster shells for $75 \mathrm{c}$; sold the bone grinder on hand for \$8; eggs gathered8@24 cts.

Dec. 4. Eggs gathered $15 @ 24$ cts.; labor 1/2 hour.

“5. Labor 1 hr.; 2 chickens, 8 lb. used or sold @ 10 cts. per 1b.; 19 eggs gathered@25 cts. Count the chickens remaining and place the number in the "No. Fowls" column.

Dec. 6. Added to investment a pen of three fowls for $\$ 20$; labor $1 \mathrm{hr}$; 16 eggs gathered@25 cts. Enter number of fowls on hand.

Dec. 7. Labor 1 hr.; 18 eggs gathered @ 26 cts.; 10 chiфkens, 45 lb. sold @ 10 cts.

“ 8. I/2 hr. labor; 14 eggs gathered@25 cts.

“ 9. I/4 hr. labor; 17 eggs gathered @ 26 cts.

“ 10. 100 lb. granulated bone bought for $\$ 3$; labor I/2 hr.; 13 eggs gathered @, 26 cts.

Dec. 11. I/4 hr. labor; 22 eggs gathered @26 cts.

“ 12. 1 hr. labor; purchased glass for repairs 32 cts.; eggs $15 @ 27$ cts.

“13. Bought 100 lb. mica grit for 75c;1 hr. labor; 21 eggs@27c.

“ 14. I/2 hr. labor; 16 eggs @ 27c.

“ 15. I/2 hr. labor; 100 lb. Kaffir corn bought for $\$ 1.50 ; 13$ eggs@ $@ 27 \mathrm{c}$.

“16. 1 hr. labor; 18 eggs @28c. 


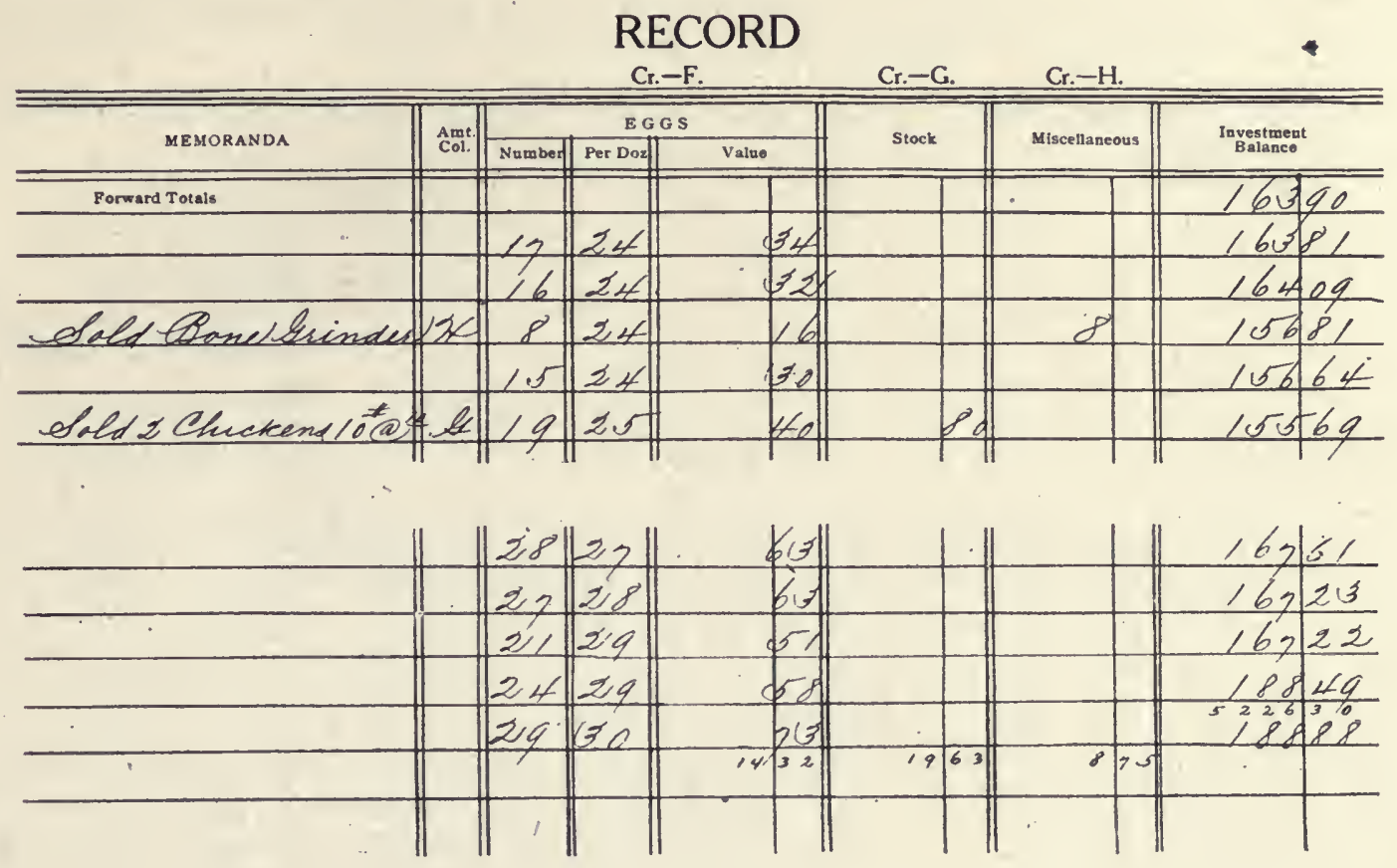

Dec. 17. 1 hr. labor; paid poultry association dues \$1;24 eggs@ 28c:

“18. 1/4 hr. labor;17 eggs@28c.

“19. 1 hr. labor; 29 eggs@27c.

“20. I/2 hr. labor; bought $100 \mathrm{lb}$. poultry mash for $\$ 1.75 ; 29$ eggs@ $@ 27 \mathrm{c} ; 24$ chickens sold,96 lb.@10c.

Dec. 21. 1/2 hr. labor; 21 eggs@28c.

“22. I/4 hr. labor; 21 eggs @ 28c; sold 25 lb. granulated bone for 75c.

“23. 1 hr. labor; bought 100 lb. charcoal for $\$ 1.50 ; 26$ eggs @ 28c; sold 10 chickens, 45 lb.@101/2 cts.

Dec. 24. Bought 1 dry food hopper $\$ 1.50 ; 1$ hr. labor; 27. eggs @ 28c.

" 25. 1/2 hir. labor; 29 eggs @ 28c.

“26. Paid for advertisement in poultry journal \$3; 1 hr. labor; 23 eggs@28c.

“27. 11/2 hr. labor; bought 100 lb. beef scraps for $\$ 3.50 ; 28$ eggs @ 27c.

“28. 1 hr. labor; 27 eggs@28c.

“29. 2 hr. labor; 21 eggs@29c.

“30. 1 hr. labor; bought 45 bu.corn@48c;24 eggs@29c.

“ 31. Before making entries for the last day of the month, foot the Investment Balances column inclucling the balance carried forward. The total of the daily balances equals in value the entire amount invested for one day. Find the interest on this at 6 per cent (point off 3 places and divide by 6 ), and charge the interest in the debit miscellaneous columnn. Complete the record of this day with entry of 1 hour labor;29 eggs gathered @ 30c.

Proof of Work. Foot all columns in red ink. Be careful not to include red ink totals at top of colunms. The balance at beginning of month plus the sum of debit footings less the sum of credit footings equals balance at close of month if work is correct.

Loss or Gain. The loss or gain for any period may be found by comparing the last balance with the value of property on hand. For example, if on taking an inventory we find that we have on hand charged in column B $\$ 25.85 ; \mathrm{C} \$ 106.22 ; \mathrm{D} \$ 59.56$; and $\mathrm{E} \$ 3$, the 
sum of these, $\$ 194.63$, will show a net gain for the month if greater than the last balance or a net loss if less than the last balance.

Continuing Next Month. Carry the inventory amounts forward (red ink), also number of fowls and investment balance (black ink) as before.

\section{QUESTIONS}

1. How many hours were given to poultry raising during the month?

2. How would you find the average egg prodution per fowl?

3. How much is now invested in the poultry industry?

4. What is the value of the entire investment for the month?

5. What is the total of returns for the month?

6. How would you find the total feed cost for the month? (Ans. By subtracting the inventory total of feed on hand from the entire total of feed column,)

7. How can the total profit for the month be found? (Ans. By subtracting the last investment balance from the total present value of all property that has been charged in the several debit columns.)

8. How should a following month's record be opened?

9. Why is interest included as a charge on the last day of the month?

10. How can the actual investment in this business on a given date be found?

\section{Farm Set}

Jan. 1, 1911. E. A. Atkinson, farmer, decides to keep a full set of books so arranged as to show the following facts of his farming business:

1. The amount actually invested at any one time in any department.

2. The profit or loss on any department.

3. The outlay necessary for the profitable maintenance of any department.

4. The waste, if any, that may be eliminated.

5. The amount and kind of his resources and liabilities.

6. The net profit of farming.

\section{OPENING THE BOOKS}

Inventory. The first step in preparing to open the books is to take an inventory of all property and debts. On a farm this inventory should be listed on journal paper with great care to include everything of value about the place and to give to it a fair valuation. After the first inventory, subsequent inventories will be found less difficult, as the first one will be on record for comparison. When the inventory is completed, copy it neatly in the journal. The following are the items: 
Inventory of Real Estate and Personal Property of E. A. Atkinson's Farm-S. E. I/4, Sec. 7, Trup. 83 N., R. $7 W ., 5$ P. M.

\section{RESOURCES}

1. 160 Acres Land less Buildings................ \$16000.00

2. Farm House and Improvements, Family use......... 2700.00

3. Buildings for use of Teams.................. 420.00

4. Buildings for use of Dairy................ 950.00

5. Buildings for use of Hogs................ 300.00

6. Buildings for use of Poultry............... 116.50

7. Buildings for storage, including corn cribs, wheat bin, etc. 250.00

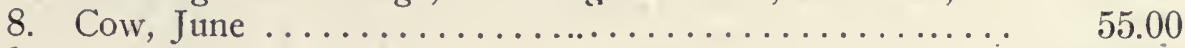

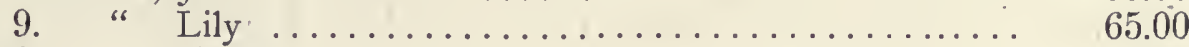

10. “ Cremo ......................... 40.00

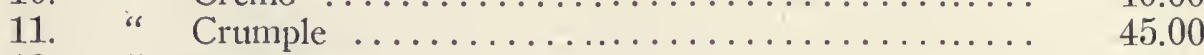

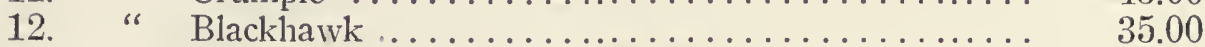

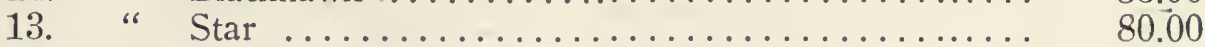

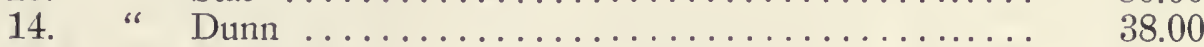

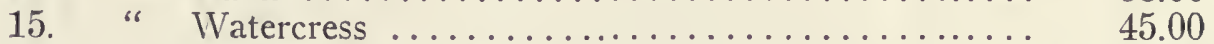

16. "Spotty ..................... 50.00

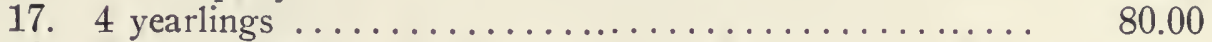

18. 3 two-year-olds . ...................... 90.00

19. 1 Cream Separator....................... 42.00

20. I Churn and attachments.................. 58.00

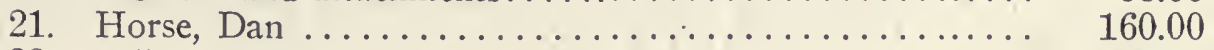

22. " Caesar .......................... 200.00

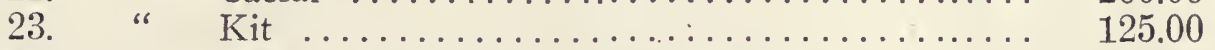

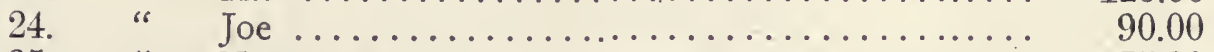

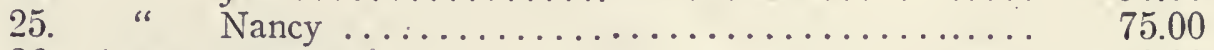

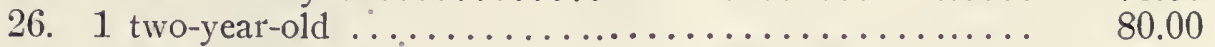

27. 1 Gang Plow............................ 45.00

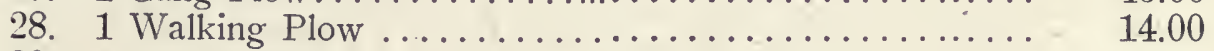

29. 1 Disc Harrow . . . . . . . . . . . . . . . . . . 18.00

30. 2 Corn Cultivators ......................... 72.00

31. 1 Farm Wagon............................ 56.00

32. 1 low Wagon........................... 40.00

33. 1 Corn Planter....................... 28.00

34. 1 Manure Spreader........................ 22.50

35. Harness ........................... 37.50

36. 30 head Hogs, 4500 lb., per cwt......@@\$7.00..... 315.00

37. 77 Chickens, 272 lb.............@@ .10..... 27.20

38. Chicken Feed carried over.................... 5.10

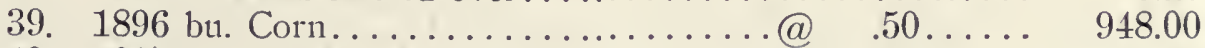

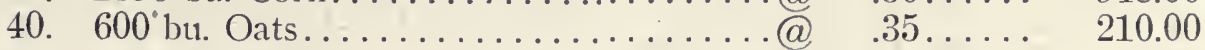

41. 190 bu. Wheat.................@ $90 \ldots . . . . .171 .00$

42. 42 tons Timothy..................@

43. 10 tons Prairie Hay...............@

44. 16 tons Clover...................@

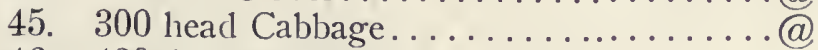

46. 420 bu. Potatoes...................@

47. 200 bu. Turnips.................@

48. 480 lb. dressed Pork.............@

49. 300 lb. dressed Beef................@

50. 20 Cords Wood.................@

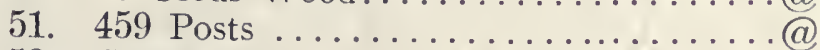

$8.00 \ldots \ldots \quad 336.00$

$4.00 \ldots \ldots .40 .00$

$7.50 \ldots . \quad 120.00$

$.04 \ldots \ldots-12.00$

$45 \ldots \ldots .00$

$.25 \ldots \ldots .00$

$.08 \ldots \ldots \quad 38.40$

$.06 \ldots . .18 .00$

$5.00 \ldots \ldots=100.00$

$.18 \ldots \ldots \quad 82.62$

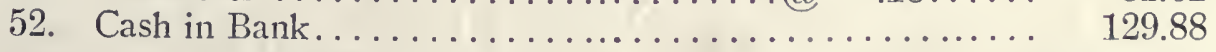

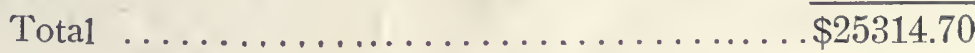




\section{LIABILITIES}

53. Mortgage note favor Monarch Insurance Co., due Jan. 1, 1913 , with interest at $5 \%$ payable July 1 and Jan. 1 until paid. Part purchase price of land. Next inter-

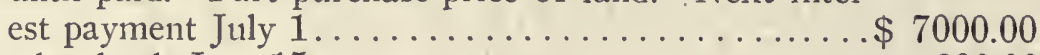

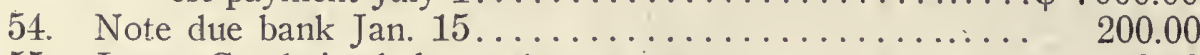

55. James Goodwin, balance due on acct............ 49.69

56. A. A. Wells \& Co halance due on acct........... 178.29

57. W. Cushman, balalice due on acct............ 5.04

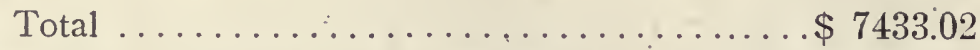

As shown in the model, number the items in the inventory 1 to 57 for convenient reference later on.

Ledger. The general accounts of the ledger will include Proprietor's Investment, Casl, Merchandise, Real Estate, Chattels, Dairy, Teams, Hogs, Poultry, Orchard, and Labor.

Other departments as needed will be opened. Give each account one page of ledger: space. The general accounts will occupy pages 1 to 20 . The order of their entry is given under "Opening the Ledger" on the following page.

The personal accounts are to be entered in the personal division of the ledger. Be careful to make full use of the explanatory space. For example, a long time note should have explanation showing to whom given, the terms of payment, etc., thus making a convenient reference. When personal accounts are opened, any conditions or explanations of the account should be recorded at the beginning of the account. Thus, an account opened with an employee should give a brief memorandum of the terms of his employment, at the top of the ledger account.

\section{FIRST JOURNAL ENTRY}

The inventory which has been spread on the journal in memorandum form should now be reduced to debit and credit entries. Before considering the titles to be used in cletail, observe that the journal has two special debit and credit columns, which are footed monthly and posted from the general columns as single items.

In making the opening journal entry, total the items Nos. 1 to 7 of the inventory and charge Real Estate with their sum. Total items Nos. 8 to 51 and charge Chattels. Charge Cash (in general column) with No. 52:

Credit Nos. 53 an 54 to Notes Payable. Credit Nos. 55 to 57 to the respective persons owed. Credit E. A. Atkinson, Proprietor, with the difference between the total debits and credits entered.

Rule and total the opening entry as shown in the model form.

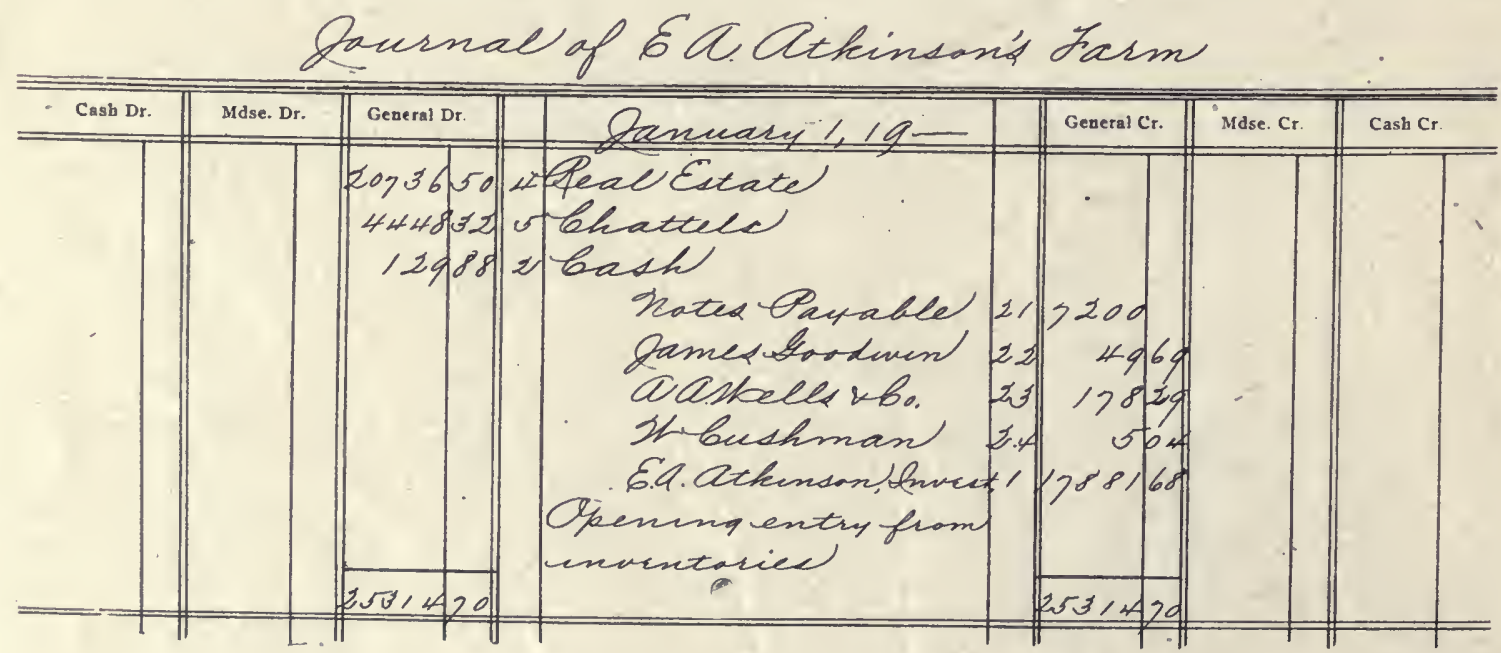




\section{OPENING THE LEDGER}

It has been determined that accounts will be kept with each of the general divisions of the business named before. Enter the titles in the general ledger, one page each, reserving page one for the proprietor, and opening the other general accounts, giving Cash page 2, Merchandise 3, Real Estate 4, Chattels 5, Dairy 6, Teams 7, Hogs 8, Poultry 9, Orchard 10, Labor 19, General Expense 20. (Reserve pages 11 to 18 for crop accounts that will be opened later in the year.) Enter the accounts with notes and persons beginning with Notes Payable in the second division of the ledger, on page 21, giving one page to each account. Be careful to index all accounts.

Post the proprietor's credit on page 1. Likewise post Real Estate, Chattels, and Cash to the respective accounts, using the explanatory space in each instance.

When the financial accounts are posted, the explanatory space should be freely used describing notes and the itemized debits and credits of the accounts with persons. An account with a person should be self-explanatory, so that any discussion relative to it would not, as a rule, require reference to the original entry.

Post all accounts in the opening entry.

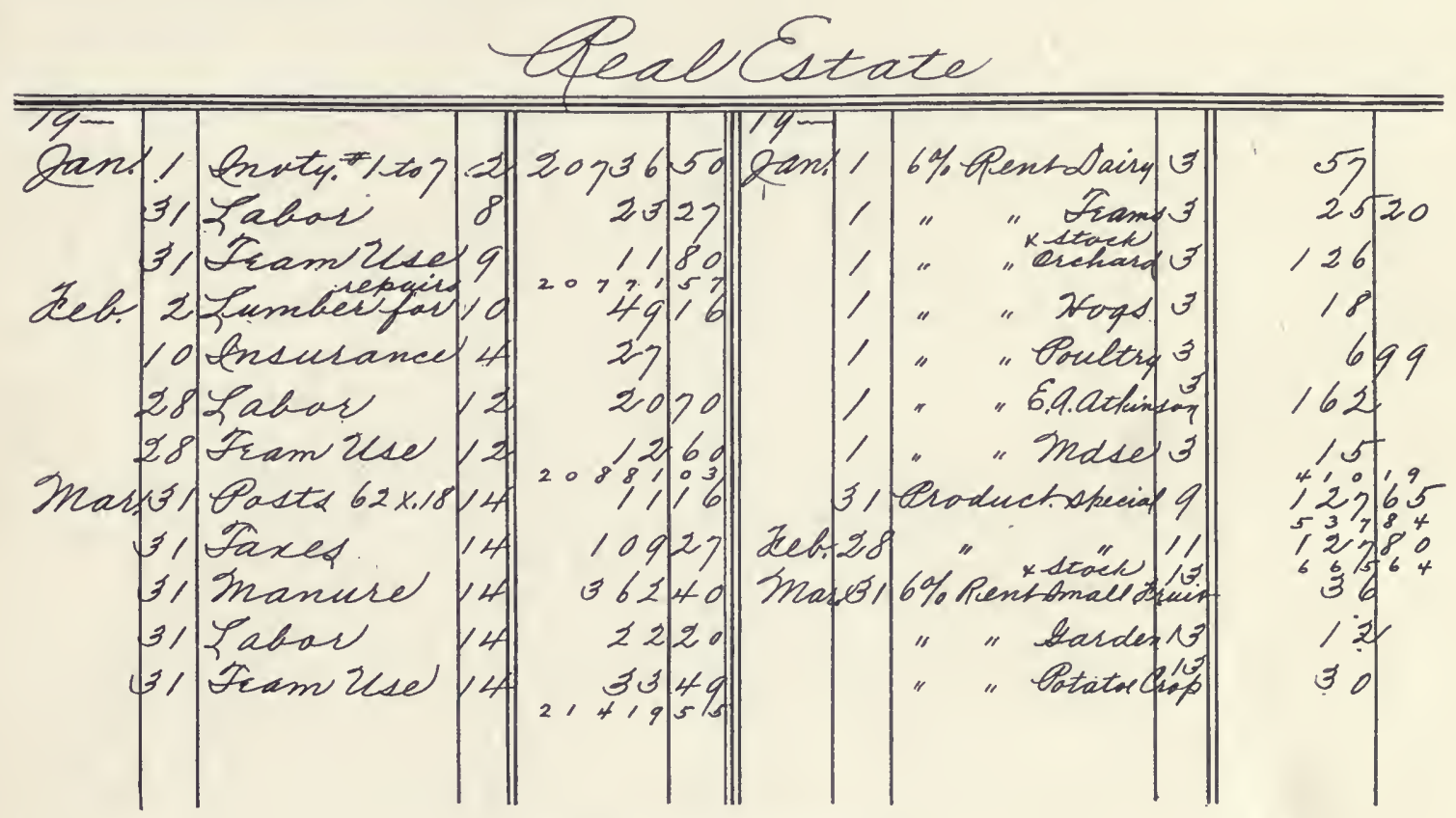

THE TRIAL BALANCE

A continuous trial balance book is used. This book contains the account titles at the left with columns at the right for the monthly trial balances of a year. In entering the titles, follow the order in the ledger, and leave blank spaces for such pages as are not used. Notes Payable, the first of the financial accounts, would be written on line 21 of the trial balance, and lines 7 to 20 would not be required in the opening trial balance.

After entry, if the trial balance proves, you may consider the books opened.

\section{USE OF THE GENERAL ACCOUNTS}

An understanding of the use of the general accounts (those on pages 3 to 20 ) is essential. Study carefully the following facts.

Merchandise. Every salable or usable thing produced on the farm (for example, corn, hogs, wheat, fruit, milk, eggs), is charged to this account as soon as the farm process of preparing it is completed. It is then to be disposed of and when so disposed of, Merchandise account is credited. Merchandise is the trading account of the farm.

Real Estate. The cost of the land, buildings and other permanent improvements and any labor, cash, or property expended upon it is charged to this account. Real Estate is cred- 
ited with the rental value of real property used in any of the departments, as for dairy, for storage of products, etc. Other.values directly from the land as wood, wild fruits, etc., would credit to this account. If the farm is operated to full capacity, the real estate account should show a net profit of 2 to 6 per cent.

Cliattels. This account is charged with the value of all personal property not pertaining to any department of farm work. Such property as is appropriated to any special department is charged to that department and a corresponding credit made to Chattels account. It will be noted that this account would not ordinarily show much gain or loss, but simply represents personal property not classified.

Crops. When active farming opens, an account is opened with each crop; as corn, oats, potatoes, etc. Each of these is to be charged with the rental value of land, seed, labor, and other cost, and credited with product.

Dairy. Charged with the cost and maintenance of the milch cows, and credited with the product.

Teams. Charged with cost and maintenance of farm draft animals and all farm machinery dependent on horse power; and credited with the value of their daily use.

Poultry, Garden, Orchard, and all similar accounts are charged with entire cost of rental, stock, labor, etc., and credited with product.

Labor. Charged with wages and board of laborers and credited when the labor done is distributed to the departments affected.

\section{BLOCKING OUT THE YEAR}

It is impossible to decide in any one day the entire operations of a year on the farm. But the main divisions of industry can be blocked out on January 1, and such changes as are made from the original plan or additions to it can be considered and entered at a later date.

Mr. Atkinson divides the accounts for the year's work as follows:

The products of the farm will be charged to Merchandise account together with the rental of the buildings used for storage purposes. Make a journal entry debiting Merchandise with inventory Nos. 38 to 51 , and $6 \%$ on No. 7, crediting Chattels and Real Estate.

The following is the entry:

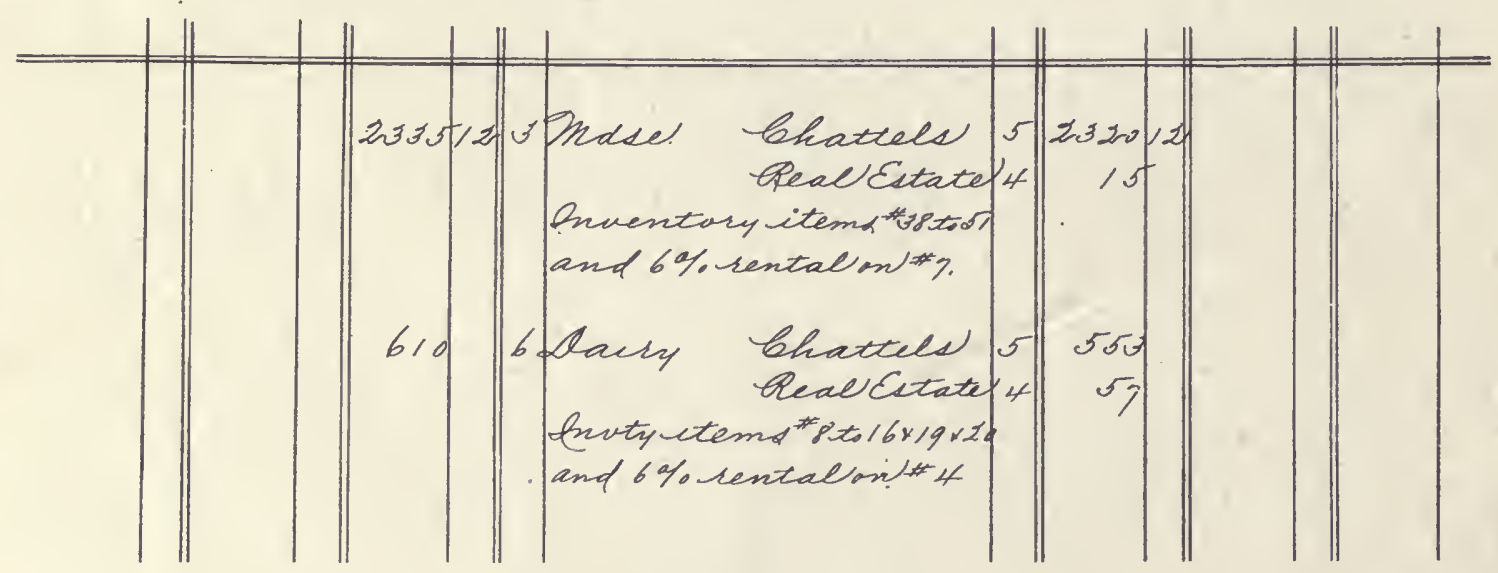

For the Dairy he will use Building (No. 4), Cows (Nos. 8 to 16), Separator (No. 19), and Churn and attachments (No. 20), as listed in the inventory.

Charge Dairy with $6 \%$ on $\$ 950$ for rental of building one year and credit Real Estate, also with the inventory value of Nos. 8 to 16,19 , and 20 ; and credit Chattels.

Charge Teams account with $6 \%$ on No. 3 and with inventory value of Nos. 21 to 25 , and 27 to 35 ; crediting Real Estate and Chattels.

Charge Hogs account with No. 36 and $6 \%$ on No. 5 ; making proper credits.

Charge Poultry with Inventory No. 37 and $6 \%$ on No. 6, making proper credit.

Charge Orchard with $\$ 6$ rental on one acre of ground and the trees on it, the latter valued at $\$ 120$. Credit the entire amount to Real Estate: 
Charge E. A. Atkinson (Personal account) with annual rental on No. 2 at $6 \%$; crediting Real Estate.

Note that all property in the inventory has been charged to the departments concerned except the ground use, which is to be charged to crops later, and the items of inventory Nos. 17,18 , and 26 which remain in Chattels account until a use or sale of them is made.

Post the entries to the ledger and carry out the balances. Open an account with E. A. Atkinson, personal, in the financial division of the ledger. Be sure to itemize in the ledger what each charge or credit is for.

Before going further, glance over the ledger. On the first page, $\$ 17881.68$ shows that the business owes this amount to the proprietor as net investment. The Cash account shows a debit balance of $\$ 129.88$ on hand. Merchandise account shows salable products of farm awaiting disposition amounting to $\$ 2335.12$. Real Estate account shows a balance of $\$ 20,326.31$ after the several credits are posted. The credits amounting to $\$ 410.19$ represent $6 \%$ of the Real Estate-value in use. When all the fields are put into use, a total credit equal to $6 \%$ of the original inventory value should appear. This profit will be reduced by charges for taxes, maintenance, etc. Chattels account shows a debit balance of $\$ 250$, representing that value of chattels on hand for which no present use is found. The remaining general accounts should show in the debit column the actual investment in each. The actual investment in each department is of great importance and should be carefully considered with a view to getting returns proportionate to the investment.

\section{DAILY REPORTS}

The memoranda from which current entries are made should be reported daily on cards and the cards held for entry, and after entry they should be placed in a package for possible future reference. The card is so printed as to show where and how long a given person worked during the day, what team work was done, the products resulting from the day's work, and the general business dealings carried out by him.
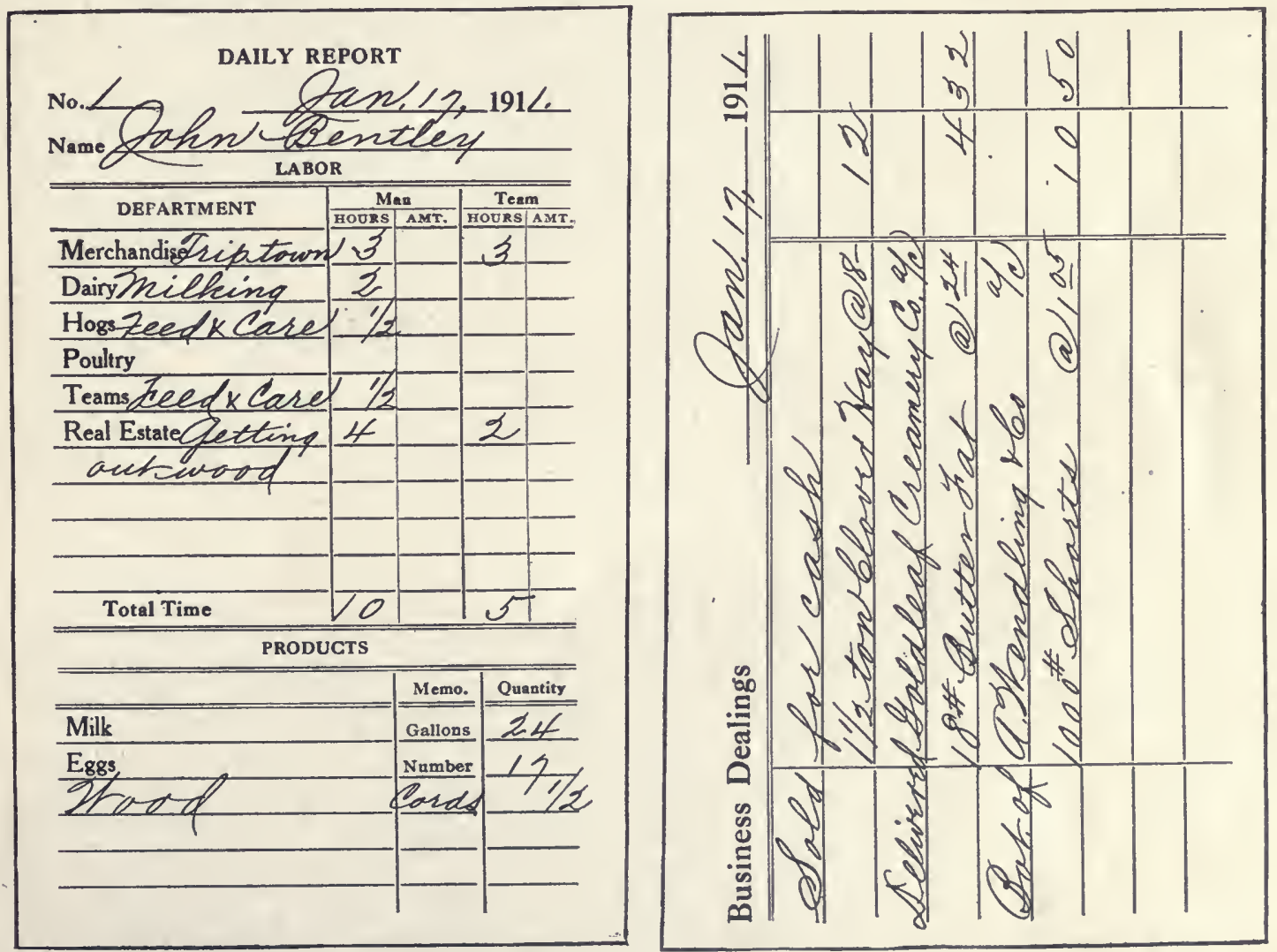

The above card shows on front and reverse sides the day's report of John Bentley, farm hand, on Jan. 17, 1911. 
Notice that he spent 4 hr. self and 2 hr. tean in timber getting out wood; 3 hr. with team in delivery of merchandise; $2 \mathrm{hr}$. in dairy work; $1 / 2 \mathrm{hr}$. in care of hogs; $1 / 2 \mathrm{hr}$. in care of teams; 24 gal. milk was taken, 17 eggs gathered, and $1 / 2$ cord of wood was brought up.

The reverse side of the card shows that he took to market and sold hay for cash $\$ 12$, he delivered $18 \mathrm{lb}$. butter fat to creamery worth today 24c per 1b., and brought back $1000 \mathrm{lb}$. shorts for cow feed worth $\$ 1.05$ per cwt.

\section{ROUTINE ENTRIES}

Routine entries in farm books are conveniently made daily, weekly, or monthly. The summaries from these entries should be made on the last day of the month. These will be illustrated as soon as sufficient memoranda is gathered. Whatever the interval decided on, the time selected should be reserved for that purpose, so that the habit of making the entries at an appointed time may be formed.

\section{EMPLOYEES' LABOR}

In this set labor will be computed at a certain rate per month including board or $\$ 15$ per month higher without board. The monthly wage plus board will be divided by 250 to give the value of labor by the hour. Thus $\$ 30$ wages $+\$ 15$ board $=\$ 45 \div 250=18$ cts. per hour. The owner of the farm is credited in personal account with the board of employees and the labor account is charged for the same.

The following is the list of persons receiving credit for labor beginning Jan. 1, 1911 :

E. A. Atkinson, Manager, $\$ 60$ per month. Board not considered. Time to be distributed at $24 \mathrm{c}$ per hour.

E. P. Johnson, $\$ 30$ per month and board. Time to be distributed at $18 \mathrm{c}$ per hour. Engaged for one year to Dec. $31,1911$.

Jonas Overburg, $\$ 20$ per month and board. Time distributed at 14 cts. per hour. Engaged by the month.

Open ledger accounts with Johnson and Overburg and write across the ledger the memoranda pertaining to each. hour.

Team use, including horses, vehicles, and machinery, is to be distributed at 20 cts. per

When the daily reports of time and product are handed in, it is the bookkeeper's place to extend the proper prices opposite each item and make entries in the summary sheets as before explained. These summary sheets are footed monthly and charges are made to the department accounts, and the totals are credited to Labor and Teams.

Entries of business transactions found on the reverse side of the report card should be made in the journal.

The payments of money in currency or by check are not distinguished in this set, for the reason that the accounting is not affected by such distinctions. The monthly cash balance as shown in the ledger is reconciled with cash on hand and in the bank as in any other business.

In the month of January following, the student is expected to make out the daily report cards of Atkinson, Johnson and Overburg, as they should make them, and then, as bookkeeper, record them in the blank books.

\section{MEMORANDA FOR THE REPORT CARDS}

\section{JANUARY 1}

E. A. Atkinson spent $1 \mathrm{hr}$. in care of hogs.

Date a report card "Jan. 1, 19-," fill in the name "E. A. Atkinson," and enter "1" opposite Hogs on card in the column headed man. Do not fill in the amount. Place the card away for entry in the books Saturday, Jan. 7.

E. P. Johnson spent 4 hr. in dairy work. The milking consisted of 27 -gallons.

Date and fill E. P. Johnson's card, placing the number of hours after Dairy and the number of gallons in day's milking after Product. Place the card with E. A. Atkinson's card for entry next Saturday. 30 eggs.

Jonas Overburg spent $2 \mathrm{hr}$. in care of poultry and $2 \mathrm{hr}$. in care of teams. He gathered

Prepare Overburg's ticket and place his card with the others of Jan, 1.

Hereafter in January, prepare tickets for all hands from the memoranda and place the tickets in the package for entry at the close of the week. 


\section{JANUARY 2}

E. A. Atkinson's report:

Labor-Chopped wood in timber lot $8 \mathrm{hr}$. (Real Estate); 2 hr. self and team in sale of 1 load corn (Mdse.) ; 1 hr. in care of hogs.

Product-1 cord wood and 17 posts.

Dealings-Sold 52 bu. corn@ @5 cts. for cash.

Records of business dealings (reported on reverse side of card) should be journalized on the date of the transactions. They frequently involve receipt or payment of cash which should have immediate entry.

E. P. Johnson's report:

Labor- 5 hr. self and $2 \mathrm{hr}$. team in timber (Real Estate); $5 \mathrm{hr}$. in dairy.

Product-26 gal. milk and 1 cord wood.

Jonas Overburg's report:

Labor -4 hr. self and team delivering milk (Mclse.); 2 hr. in care of poultry; 4 hr. in care of horses and repairing harness.

Product-36 eggs gathered.

Dealings-Sold milk tickets (representing 12 gal.) for cash $\$ 3$.

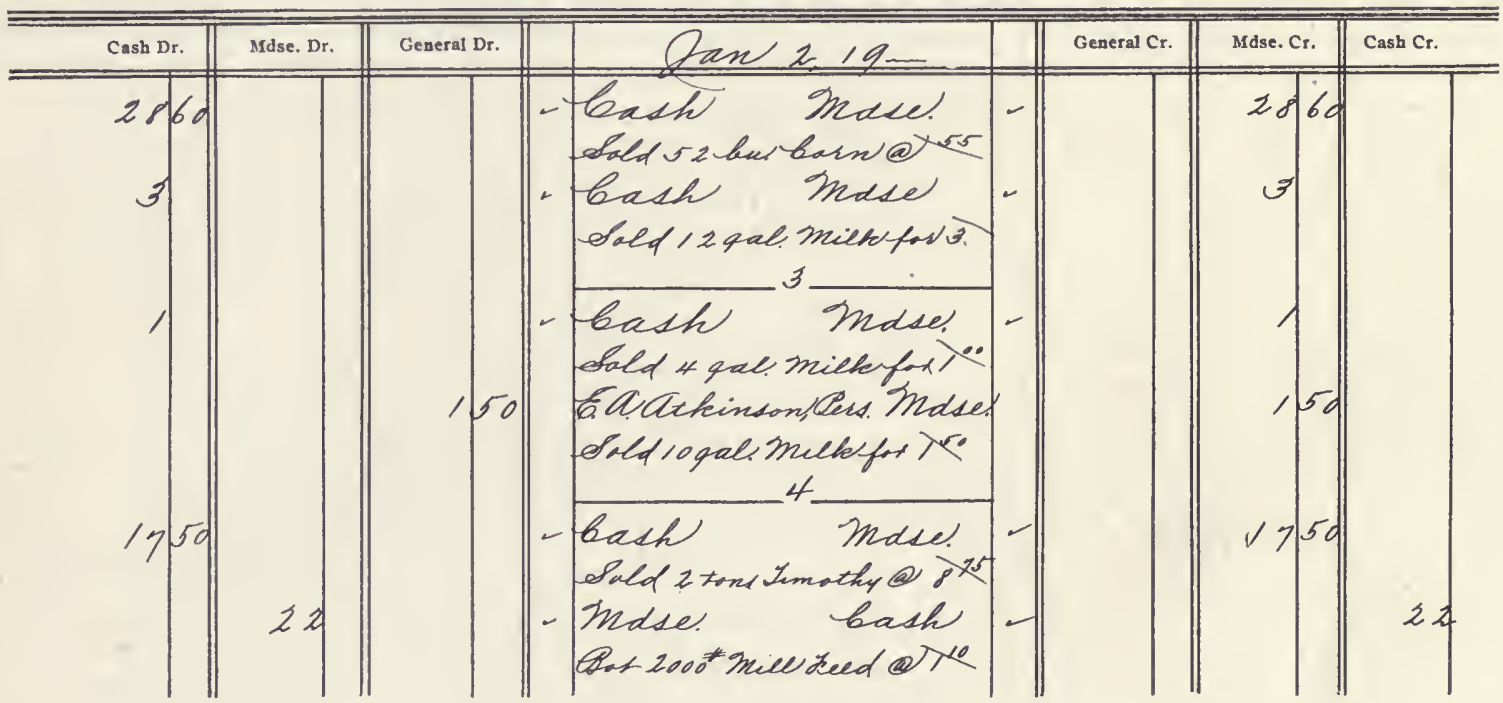

JANUARY 3

E. A. Atkinson's report:

Labor-9 hr. self and 4 hr. team in timber getting out wood, 1 hr. in care of logs.

Product-2 cords wood and 10 posts.

E. P. Johnson's report:

Labor-6 hr. self and 2 hr. team in timber and hauling out wood; 4 hr. in dairy.

Product-26 gal. milk, 1 cord wood, 10 posts.

Jonas Overburg's report: teams.

Labor $-4 \frac{1}{2}$ hr. self and team delivering milk, $3 \frac{1}{2}$ hr. in care of poultry, 2 hr. in care of

Product-24 eggs gathered.

Dealings-Sold milk tickets (4 gal.) for cash $\$ 1$. Sold E. A. Atkinson on account milk tickets (10 gal.) for $\$ 1.50$.

\section{JANUARY 4}

E. A. Atkinson's report:

Labor $-8 \mathrm{hr}$. self and 6 hr. team in timber, $2 \mathrm{hr}$. self and team delivering merchandise, $1 \mathrm{hr}$. in care of hogs.

Product-2 cords wood.

Dealings-Sold.2 tons timothy hay for cash@ @8.75. Bought for cash 2000 lb. millfeed for $\$ 22$. (Charge Mdse.) 


\section{E. P. Johnson's report:}

Labor $-4 \mathrm{hr}$. chopping wood in timber, $3 \mathrm{hr}$. self and team delivering merchandise, 3 hr. in dairy.

Product-27 gal. milk, $3 / 4$ cord wood.

Dealings-Sold Goldleaf Creamery Co., on account, 27 lb. butter fat @ 24 cts. Sold for cash $1 \frac{1}{2}$ tons timothy hay @ $\$ 8.75$.

Jonas Overburg's report:

Labor $-5 \frac{1}{2} \mathrm{hr}$. self and team delivering merchandise, $2 \mathrm{~T} / 2 \mathrm{hr}$. in care of poultry, $2 \mathrm{hr}$. in care of teams.

Product-43 eggs gathered. cash $\$ 2$.

Dealings-Sold for cash 2 tons timothy hay @ $\$ 8.50$. Sold milk tickets (8 gal.) for

E. A. Atkinson's report:

JANUARY 5

Labor $-8 \mathrm{hr}$. chopping wood in timber, $2 \mathrm{hr}$. self and team delivering merchandise, 1 hr. in care of hogs.

Product-2 cords wood.

Dealings-Sold for cash 1 cord wood for $\$ 6.50$.

E. P. Johnson's report: dairy.

Labor-2 $\mathrm{hr}$, chopping in timber, $4 \mathrm{hr}$. self and team delivering merchandise, $4 \mathrm{hr}$. in

Product-16 posts, 27 gal. milk.

Dealings-Sold for cash 79 posts @ 21 cts.

Jonas Overburg's report:

Labor $-5 \mathrm{hr}$. self and team delivering merchandise, $5 \mathrm{hr}$. in care of poultry, $2 \mathrm{hr}$. in care of teams.

Product-35 eggs gathered.

Dealings-Sold A. A. Wells \& Co. on acct., 12 doz. eggs @ 29 cts. Bought of A. A. Wells \& Co., on acct., 1 brl. salt for $\$ 2$, gluten feed for $\$ 5.40$. (Debit Mdse. with the purchase.)

E. A. Atkinson's report:

JANUARY 6

Labor $-4 \mathrm{hr}$. self and team getting wood from timber, $3 \mathrm{hr}$. self and team hauling hay to market, $1 \mathrm{hr}$. in care of hogs, $1 \mathrm{r} / 2 \mathrm{hr}$. in care of teams.

Product-1 cord wood.

Dealings-Sold for cash 11/2 tons timothy hay @ \$8.50. Paid Jonas Overburg cash on acct. $\$ 10$.

E. P. Johnson's report:

Labor $-5 \mathrm{hr}$. self and team getting wood from timber, $5 \mathrm{hr}$. in dairy.

Product-3/4 cord wood, 13 posts, 25 gal. milk.

Jonas Overburg's report:

Labor $-7 \mathrm{hr}$. self and team delivering merchandise, $1 \mathrm{hr}$. in care of poultry, $2 \mathrm{hr}$. in care of teams.

Product-28 eggs gathered.

Dealings-Sold A. A. Wells \& Co., on acct., 40 bu. potatoes @ 55 cts. Sold milk tickets (20 gal.) for cash $\$ 5$, also 3 qts. milk for cash 21 cts.

\section{E. A. Atkinson's report:}

JANUARY 7

Labor $-7 \mathrm{hr}$. self and team getting wood from timber, $2 \mathrm{hr}$. self and team delivering merchandise, $1 \mathrm{hr}$. in care of hogs.

Product-50 posts.

Dealings-Sold for cash 60 posts @ 20 cts.

E. P. Johnson's report:

Labor $-6 \mathrm{hr}$. self and team delivering merchandise, $4 \mathrm{hr}$. in dairy.

Product-27 gal. milk.

Dealings-Sold for cash 2 cords wood @ \$5.75. Sold Goldleaf Creamery Co., on acct., 23 ib. butter fat@25 cts. 
Jonas Overburg's report:

Labor $-6 \frac{1}{2} \mathrm{hr}$. self and team delivering merchandise, $1 \mathrm{r} / 2 \mathrm{hr}$. in care of poultry, $2 \mathrm{hr}$. in care of teams.

Product-41 eggs gathered.

Dealings-Sold A. A. Wells \& Co., on acct., 250 hd. cabbage@6 cts. Sold milk tickets (16 gal.) for cash $\$ 4$.

WAGE CARD

\begin{tabular}{|c|c|c|c|c|c|c|c|c|c|c|c|c|}
\hline Rate per $\mathrm{Hr}$ & $1 \mathrm{Hr}$. & 2 Hrs. & 3 Hrs. & $4 \mathrm{Hrs}$. & $5 \mathrm{Hrs}$. & $6 \mathrm{Hrs}$. & $7 \mathrm{Hrs}$. & 8 Hrs. & $9 \mathrm{Hrs}$. & $10 \mathrm{Hrs}$. & $11 \mathrm{Hrs}$. & $12 \mathrm{Hrs}$ \\
\hline $10 \mathrm{Cts}$. & 10 & 20 & 30 & 40 & 50 & 60 & 70 & 80 & 90 & 1.00 & 1.10 & 1.20 \\
\hline 11 " & 11 & 22 & 33 & 44 & 55 & 66 & 77 & 80 & 99 & 1.10 & 1.21 & 1.32 \\
\hline $12 "$ & 12 & 24 & 36 & 48 & 60 & 72 & 84 & 96 & 1.08 & 1.20 & 1.32 & 1.44 \\
\hline 13 & 13 & 26 & 39 & 52 & 65 & 78 & 91 & 1.04 & 1.17 & 1.30 & 1.43 & 1.56 \\
\hline 14 & 14 & 28 & 42 & 56 & 70 & 84 & 98 & $\begin{array}{l}1.07 \\
1.12\end{array}$ & 1.26 & 1.40 & 1.54 & 1.68 \\
\hline 15 & 15 & 30 & 45 & 60 & 75 & 90 & 1.05 & 1.20 & 1.35 & 1.50 & 1.65 & 1.80 \\
\hline 16 & 16 & 32 & 48 & 64 & 80 & 96 & 1.12 & 1.28 & 1.44 & 1.60 & 1.76 & 1.92 \\
\hline 17 & 17 & 34 & 51 & 68 & 8.5 & 1.02 & 1.19 & 1.36 & 1.53 & 1.70 & 1.87 & 2.04 \\
\hline 18 & 18 & 36 & 54 & 72 & 90 & 1.08 & 1.26 & 1.44 & 1.62 & 1.80 & 1.98 & 2.16 \\
\hline 19 “" & 19 & 38 & 57 & 76 & 95 & 1.14 & 1.33 & $1: 52$ & 1.71 & 1.90 & $\begin{array}{l}2.09 \\
\end{array}$ & 2.28 \\
\hline 20 “ & 20 & 40 & 60 & 80 & 1.00 & 1.20 & 1.40 & 1.60 & 1.80 & 2.00 & 2.20 & 2.40 \\
\hline 21 & 21 & 42 & 63 & 84 & 1.05 & 1.26 & 1.47 & 1.68 & 1.89 & 2.10 & 2.31 & 2.52 \\
\hline 22 & 22 & 44 & 66 & 88 & 1.10 & 1.32 & 1.54 & 1.76 & 1.98 & 2.20 & 2.42 & 2.64 \\
\hline 23 & 23 & 46 & 69 & 92 & 1.15 & 1.38 & 1.61 & 1.84 & 2.07 & 2.30 & 2.53 & 2.76 \\
\hline 24 & 24 & $\begin{array}{l}70 \\
48\end{array}$ & 72 & 96 & 1.20 & 1.44 & 1.68 & $\begin{array}{l}1.07 \\
1.92\end{array}$ & 2.16 & 2.40 & 2.64 & 2.88 \\
\hline 25 & 25 & 50 & 75 & 1.00 & 1.25 & 1.50 & 1.75 & 2.00 & 2.25 & 2.50 & 2.75 & 3.00 \\
\hline
\end{tabular}

\section{ENTRIES}

This completes the week's transactions. Count the cards turned in. Are there twentyone? Before making any entries in the summary sheets enter on the cards the wage value of the time spent correct to the nearest cent. Atkinson 24 cts. per hour, Johnson 18 cts., Overburg $14 \mathrm{cts}$., team $20 \mathrm{cts}$. Refer to the wage card in making up the distribution of labor expense on each item. Then enter the results shown on the Labor Summary and Team Use Summary and the product on the Product Summary. Having distributed the above three items, check back journal entries of the transactions which you have made with the entries appearing on the back of the cards.

When the entries have been verified, use pencil footings to show the journal in balance. The correct footings for the six columns in their order are $\$ 150.78, \$ 29.40, \$ 4672.72$, $\$ 4615.91, \$ 204.99, \$ 32$. Add the debit and credit footings to see if their totals are equal. Subtract the cash credit column from the cash balance shown in last balance book plus debit cash column of journal. After proving the footings, post all entries found in the general debit and credit columns.

\section{JANUARY 8}

E. A. Atkinson's report:

Labor-2 hr. in care of hogs:

E. P. Johnson's report:

Labor-6 hr. in dairy.

Product-27 gal. milk.

Jonas Overburg's report:

Labor-3 hr. self and team delivering milk, $3 \mathrm{hr}$. in care of poultry, $2 \mathrm{hr}$. in care of teams.

Product-32 eggs gathered.

\section{JANUARY 9}

E. A. Atkinson's report:

Labor -4 hr. self and team getting out wood, 4 hr. self and team delivering posts, 3 hr. in care of hogs.

Product-29 posts.

Dealings-Sold for cash 100 posts at 21 cts. 


\section{LABOR}

\begin{tabular}{|c|c|c|c|c|c|c|c|c|c|c|}
\hline $\begin{array}{c}\text { Day } \\
\text { of } \\
\text { Month }\end{array}$ & MEMORANDA & \begin{tabular}{|l} 
Entry \\
Mark
\end{tabular} & Miscellaneous & & Merchandis & & Real Estate & Chattels & Dairy & \\
\hline & & & & & & & & & & 82 \\
\hline 2 & & & & & & 48 & 142 & & & $\sqrt{10}$ \\
\hline$\leftarrow$ & . & & & & & 56 & 90 & & & \\
\hline 3 & E. & & & & & k.3 & 226 & $=$ & & 22 \\
\hline 2 & & & & & & & 168 & & & \\
\hline$x$ & $x \quad x$ & & $x$ & & $x$ & & $\times$ & $x$ & $x$ & \\
\hline & - & & & & & & & & & \\
\hline 11 & anThelarbo. & 2 & $\Delta k$ & Sol & & 56 & 168 & & & 84 \\
\hline 2 & 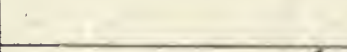 & & & & & & & & & \\
\hline 12 & Ea Keleskbo. & 2 & 18 & sd & & 96 & & & & 20 \\
\hline$\leftarrow$ & & & & & & 84 & & & & \\
\hline
\end{tabular}

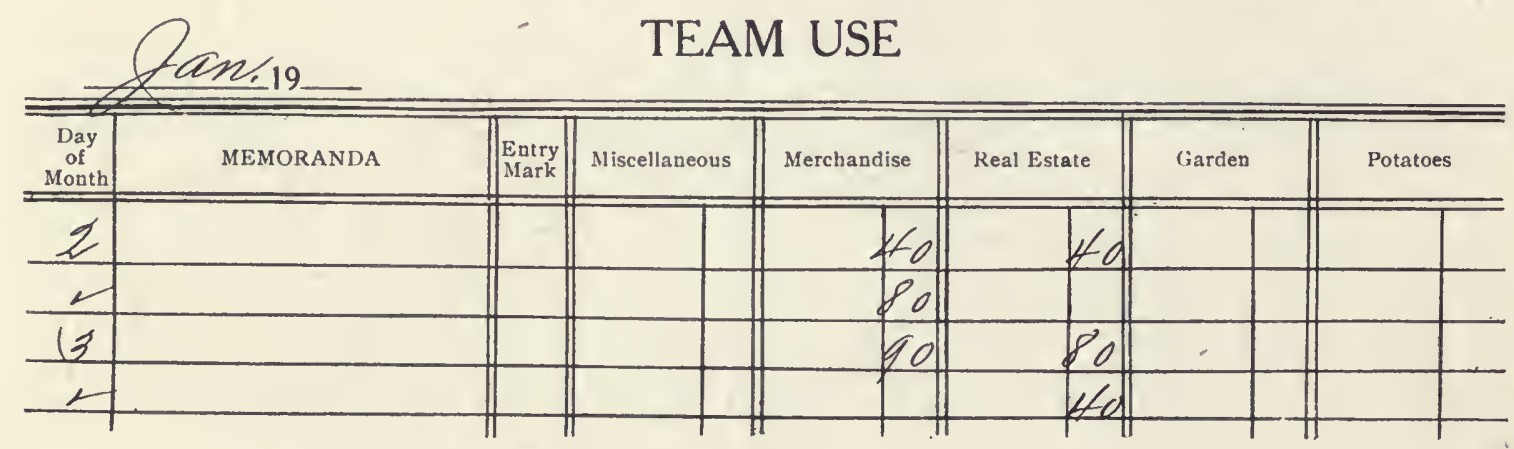

\begin{tabular}{|c|c|c|c|c|c|c|c|c|c|c|c|c|}
\hline \multirow{2}{*}{$\begin{array}{c}\text { Day } \\
\text { oft } \\
\text { of } \\
\text { Month }\end{array}$} & \multirow{2}{*}{ MEMORANDA } & \multirow{2}{*}{$\begin{array}{l}\text { Entry } \\
\text { Mark }\end{array}$} & \multicolumn{2}{|c|}{ MILK } & \multicolumn{2}{|c|}{ EGiGS } & \multicolumn{2}{|c|}{ WOOD } & \multicolumn{2}{|c|}{ Posts } & \multirow[b]{2}{*}{ Quan. } & \multirow[b]{2}{*}{$F$ Price } \\
\hline & & & \begin{tabular}{|l|l|l} 
Quantity \\
\end{tabular} & Farmil'ric & Quan & F Price & Quan & F Pricc & Quao & F Price & & \\
\hline 1 & & & $y_{1}$ & 16 & 30 & 26 & & & & & & \\
\hline 2 & & & 16 & " & 36 & " & 1 & $5^{\circ 00}$ & 17 & 18 & & \\
\hline 2 & & & & $" 1$ & & " & $\angle$ & "I & J & " & & \\
\hline 6 & & & 26 & "I & 24 & $"$ & 2 & "I & 10. & II & & \\
\hline
\end{tabular}

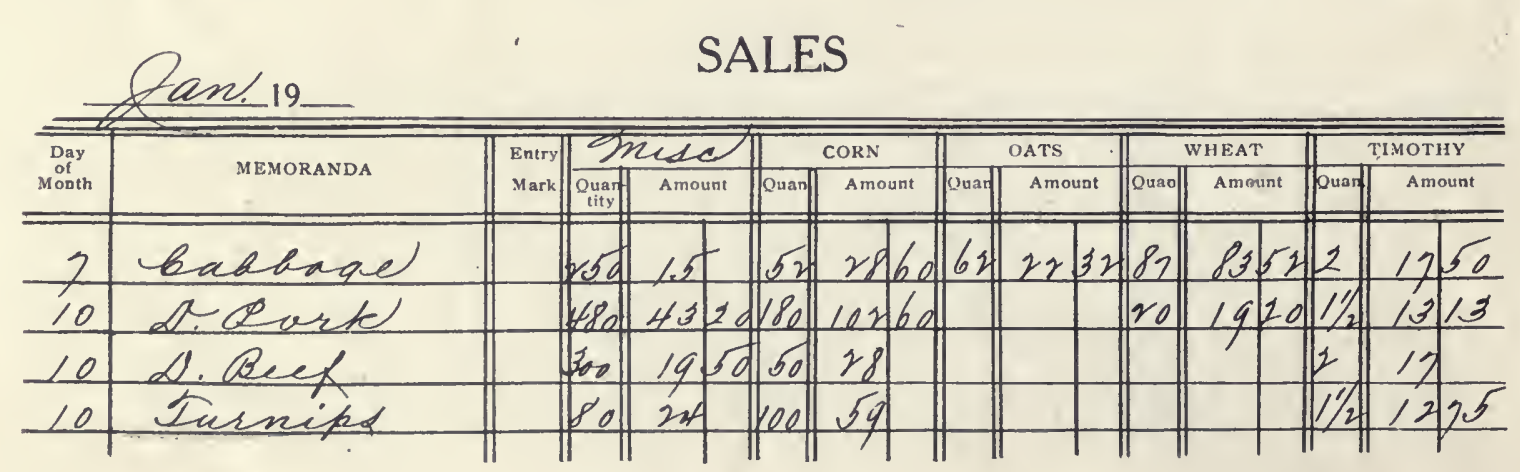




\section{SUMMARY}

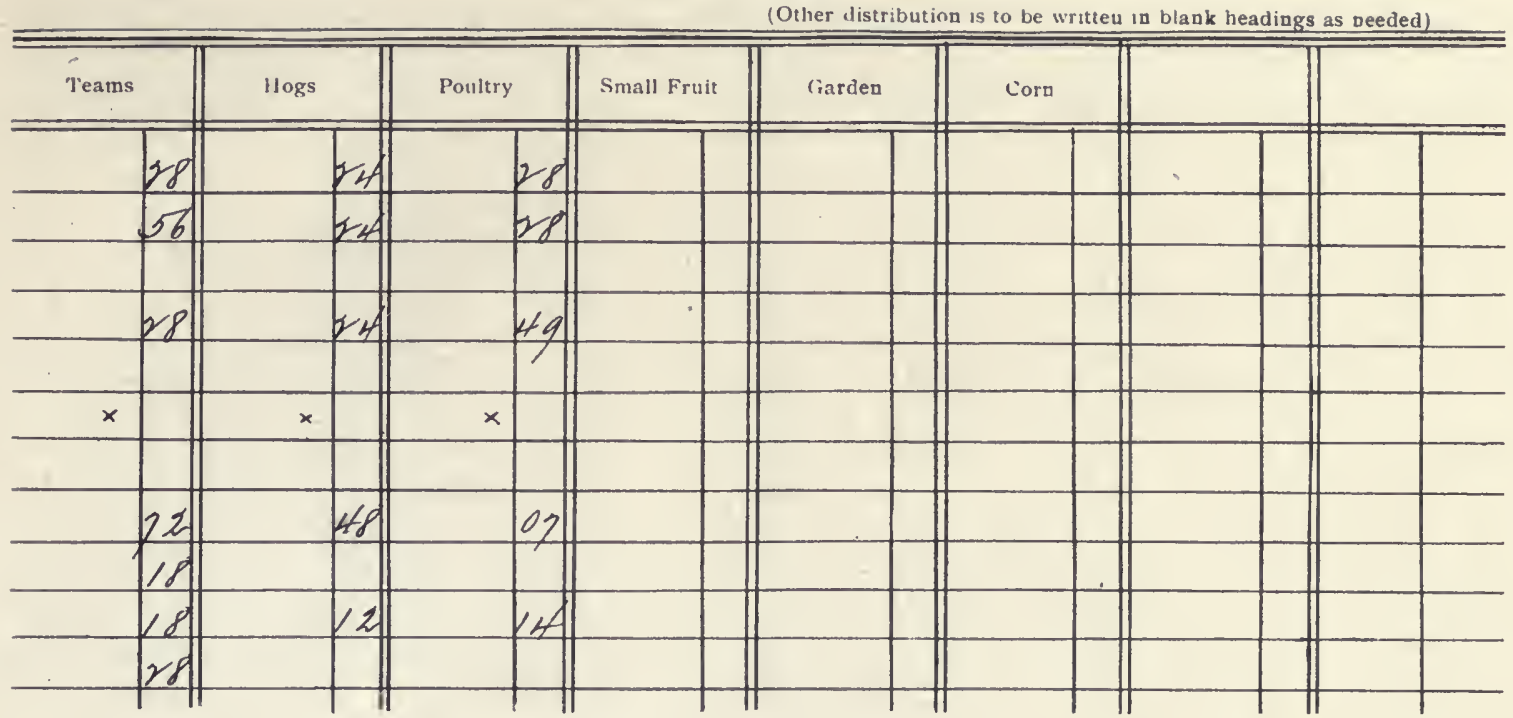

\section{SUMMARY}

(Other distr"bution to be written in blank headings as needed)

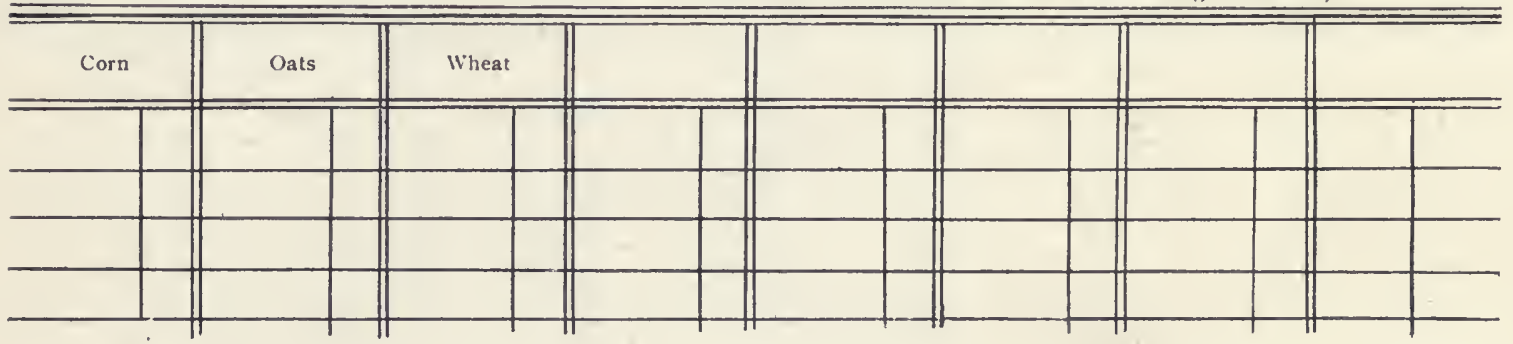

\section{SUMMARY}

(O)ther distribution to be written in blank hoadings as needed)

\begin{tabular}{|c|c|c|c|c|c|c|c|c|c|c|c|c|c|c|c|}
\hline \multirow[b]{2}{*}{ Quan } & \multirow[b]{2}{*}{ F. Price } & \multirow[b]{2}{*}{ Quan. } & \multirow[b]{2}{*}{ F. Price } & \multirow[b]{2}{*}{ Quan. } & \multirow[b]{2}{*}{ F Price } & \multirow[b]{2}{*}{ Quan. } & \multirow[b]{2}{*}{ F. Price } & \multirow[b]{2}{*}{ Quan. } & \multirow[b]{2}{*}{ P Price } & \multirow[b]{2}{*}{ Quan } & \multirow[b]{2}{*}{ F Price } & \multirow[b]{2}{*}{ Quan. } & \multirow[b]{2}{*}{ P. Price } & \multirow[b]{2}{*}{ Quan. } & \multirow[b]{2}{*}{ F. Price } \\
\hline & & & & & & & & & & & & & & & \\
\hline & & & & & & & & & & & & & & & \\
\hline & & & & & & & & & & & & & & & \\
\hline & & & & & & & & & & & & & & & \\
\hline & & & & & & & & & & & & & & & \\
\hline & & & & & & & & & & & & & & & \\
\hline
\end{tabular}

\section{SUMMARY}

(Other distribution to be written in blank headings as needed)

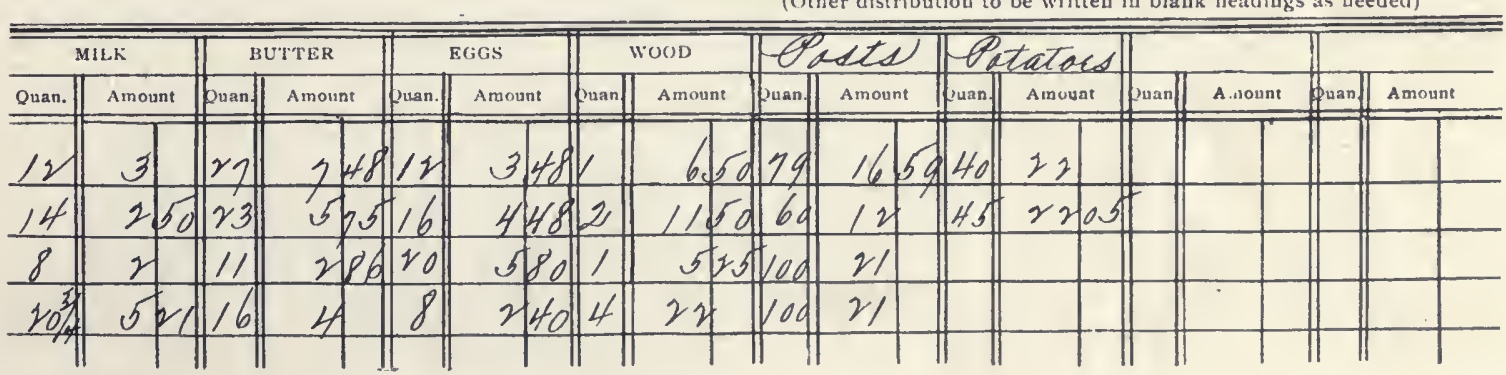




\section{E. P. Johnson's report:}

Labor $-3 \mathrm{hr}$. repairing fence, $2 \mathrm{hr}$. self and team delivering merchandise, $4 \mathrm{hr}$. in dairy, $1 \mathrm{hr}$. self and team in care of orchard.

Product-27 gal. milk.

Dealings-Sold for cash 1 cord wood for $\$ 5.25$.

Jonas Overburg's report:

Labor $-61 / 2 \mathrm{hr}$. self and team delivering merchandise, $1 \mathrm{r} / 2 \mathrm{hr}$. in care of poultry, $2 \mathrm{hr}$. in care of teams.

Product-27 eggs gathered.

Dealings-Sold Eagle Hotel, on acct., 12 gal. milk @ 22 cts. Sold milk tickets (12 gal.) for cash $\$ 3$. Sold W. Cushman, on acct., 1 cord wood for $\$ 5.50$.

E. A. Atkinson's report:

JANUARY 10

Labor $-6 \mathrm{hr}$. self and team delivering merchandise, $1 \mathrm{hr}$. in care of hogs, $2 \mathrm{hr}$. in care of teams.

Dealings-Sold for cash 180 bu. corn@ @ 57 cts. Took for personal use from merchandise included in first inventory 480 lb. dressed pork@9 cts, 300 lb. dressed beef @61/2 cts. (Charge E. A. Atkinson, Personal.)

E. P. Johnson's report:

Labor- $8 \mathrm{hr}$. self and team delivering merchandise, $5 \mathrm{hr}$. in dairy.

Product-25 gal. milk.

Dealings-Sold W. Cushman, on acct., 4 cords wood @ \$5.50. .

Jonas Overburg's report:

Labor $-5 \mathrm{hr}$. self and team delivering merchandise, $3 \mathrm{hr}$. in care of poultry, $2 \mathrm{hr}$. in care of teams.

Product-46 eggs gathered. 28 cts.

Dealings-Sold A. A. Wells \& Co., on acct., 80 bu. turnips@ @ 30 cts., 16 doz. eggs@

E. A: Atkinson's report:

JANUARY 11 teams.

Labor $-7 \mathrm{hr}$. self and team working in timber, $2 \mathrm{hr}$. in care of hogs, $3 \mathrm{hr}$. in care of

Dealings-Sold W. Cushman, on acct., 3 cords wood @ $\$ 5.50$, on grourid.

E. P. Johnson's report:

Labor-10 hr. self and team working for A. A. Wells \& Co., 1 hr. in care of teams. (Enter the time on labor card, filling in the memo space, "work for A. A. Wells \& Co.")

Dealings-Bought of. A. A. Wells \& Co., on acct., bill of goods for E. A. Atkinson's personal use, $\$ 29.61$. Debit A. A. Wells \& Co., 1 day for man and team (man $\$ 1.80$, team $\$ 3) \$ 4.80$.

The journal entry will be “A. A. Wells \& Co., Dr. \$4.80; Labor Cr. \$1.80; Teams Cr. \$3." Place check marks $(V)$ in the folio column next to Labor and Teams, to indicate that these credits will not be posted separately but will appear in the total credits of these titles for the month as posted from the summary books.

Jonas Overburg's report:

Labor $-4 \mathrm{hr}$. self and team delivering merchandise, $6 \mathrm{hr}$. in dairy, $\mathrm{t} / 2 \mathrm{hr}$. in care of poultry.

Product-22 gal. milk, 23 eggs gathered.

Dealings-Sold Eagle Hotel Co., on acct., 12 gal. milk @ 22 cts. Sold milk tickets (20 gal.) for cash $\$ 5$.

E. A. Atkinson's report:

JANUARY 12

Labor $-4 \mathrm{hr}$. self and team delivering merchandise, $5 \mathrm{hr}$. in dairy, $\mathrm{I} / 2 \mathrm{hr}$. in care of hogs.

Product-24 gal. milk.

Dealings-Sold W. Cushman, on acct., 2 cords wood @ \$5.50. Sold Goldleaf Creamery Co., on acct., 11 lb. butter fat @ 26 cts. Paid E. P. Johnson Cash on account $\$ 20$.

E. P. Johnson's report:

Labor-10 hr. self and team working for A. A. Wells \& Co., $1 \mathrm{hr}$. in care of teams.

Dealings-Debit A. A. Wells \& Co. for 1 day for man and team $\$ 4.80$. 
Jonas Overburg's report:

Labor $-6 \mathrm{hr}$. self and team delivering merchandise, $1 \mathrm{hr}$. in care of poultry, $2 \mathrm{hr}$. in care of teams.

Product-33 eggs collected.

Dealings-Sold 1 cord wood for cash $\$ 6$. Sold milk tickets (8 gal.) for cash $\$ 2$.

\section{JANUARY 13}

E. A. Atkinson's report:

Labor $-2 \mathrm{hr}$. in timber, $9 \mathrm{hr}$. self and $7 \mathrm{hr}$. team delivering merchandise, $\mathrm{I} / 2 \mathrm{hr}$. in care of hogs.

Dealings-Sold W. Cushman, on acct., 4 cords wood @ \$5.50.

E. P. Johnson's report:

Labor-6 hr. self and team delivering merchandise, $4 \mathrm{hr}$. in dairy.

Product-26 gal. milk.

Dealings-Sold W. Cushman, on acct., 3 cords wood@ @ $\$ 5.50$.

Jonas Overburg's report:

Labor $-7 \mathrm{r} / 2 \mathrm{hr}$. self and team delivering merchandise, $1 / 2 \mathrm{hr}$. in care of poultry, $2 \mathrm{hr}$. in care of teams.

Product-26 eggs gathered.

Dealings-Sold for cash 2 cords wood for $\$ 12.25$.

\section{JANUARY 14}

E. A. Atkinson's report:

Labor-9 hr. self and team at auction sale, which he distributes as follows: Dairy 3 hr., hogs 3 hr., teams 3 hr.

Dealings-Bought for cash 1 cow for $\$ 39.50$ (Dairy), 1 set harness for $\$ 14.25$ (Teams), 6 shoats for $\$ 31.50$ (Hogs), sundry household articles for $\$ 3.90$ (Atkinson Personal).

E. P. Johnson's report: dairy.

Labor- $4 \mathrm{hr}$. working in timber, $3 \mathrm{hr}$. self and team delivering merchandise, $4 \mathrm{hr}$. in

Product-27 gal. milk, 5 hogs (farm weight 1605 lb.)

Dealings-Sold for cash 5 hogs weighing 1568 lb. @ \$8.40 per cwt. (Credit Mdse.) Jonas Overburg's report:

Labor $-5 \mathrm{r} / 2 \mathrm{hr}$. self and team delivering merchandise, $2 \mathrm{r} / 2 \mathrm{hr}$. in care of poultry, $2 \mathrm{hr}$. in care of teams.

Product-34 eggs gathered.

Dealings-Sold for cash 50 bu. corn@ 56 cts. Sold milk tickets (16 gal.) for $\$ 4$.

Count the week's tickets to see that all are in-21 in number. Review your journal entries, to see that all dealings have been recorded. Foot the journal column to see that the journal is in balance. What is your cash balance?

Post the general accounts from the journal, but do not post the special column accounts until the close of the month.

Referring to the report cards, extend the amount of each labor item, and make the required entries in the summary books as you were instructed to do on Jan. 7.

On Jan. 9, place Johnson's labor 1 hr. in orchard in miscellaneous column.

On Jan. 11 and 12 place E. P. Johnson's time for working for Wells \& Co. in the miscellaneous column followed by the initial "J," indicating that the charge against Wells \& Co. has already been made through the journal. The two day's use of team is entered in like manner in the team use summary.

Observe that the summary books have one miscellaneous column each for unusual items, with a memorandum space before the item to show what it is for. The two day's labor, man and team, for Wells \& Co. would be itemized in this column. Remember that the totals of all labor columns will at the end of the month be posted to the credit of Labor account, and of all special columns to the debit of the department named at the head of the column with the exception of the miscellaneous column, the debits of which, if they concern a personal account, are posted from the journal, as it is frequently desirable to have such items posted on 
the date of the transaction. If a department is affected, the posting will be done at the end of the month.

Observe further that the summary books have a number of columns without printed heads. These columns are to be headed by the bookkeeper at certain seasons of the year when other departments become active. Thus, wheat crop, oats crop, corn crop, would require much time during certain months and would not be regarded during other months. Likewise, the columns IVood and Posts in the product summary will at a later date be discontinued. The departments requiring constant entries have printed heads in the summary books. 7 th.

You may now foot in pencil the summary columns, adding in the pencil footings of the

As an experiment, add the footings of the labor summmary and see if the labor actually reported agrees with one-half of your monthly pay roll of $\$ 140$. If it runs behind, investigate.

What value have you received from teams to date? Is the output of milk what should be expected? Is the yield of eggs satisfactory? Note that Overburg is spending less time attending to poultry than formerly. Foot in pencil A. A. Wells \& Co.'s account, to see how it stands. Has IV. Cushman still a credit balance? How much has E. P. Johnson received? The Eagle Hotel Co. ordered milk only twice. Why do they not order regularly? Ask Overburg. Does the Goldleaf Creamery Co. owe us $\$ 15.09$ or $\$ 16.09$ ? They settle by check monthly. Do we owe any notes due soon? How much cash is on hand? A person keeping books should form the habit of looking to his books for information about his business.

\section{E. A. Atkinson's report:}

JANUARY 15

Labor- $\mathrm{T} / 2 \mathrm{hr}$. in care of hogs, $1 / 2 \mathrm{hr}$. in care of poultry, $1 \mathrm{I} / 2 \mathrm{hr}$. in care of teams.

Product-31 eggs gathered.

E. P. Johnson's report:

Labor -4 hr. in dairy.

Product-28 gal. milk.

Jonas Overburg's report:

Labor-3 hr. self and team delivering merchandise.

\section{E. A. Atkinson's report:}

\section{JANUARY 16}

Labor $-3 \mathrm{hr}$. self and team getting wood from timber, 3 hr. self and team delivering merchandise, $4 \mathrm{hr}$. in care of hogs.

Product -2 cords wood, 26 posts.

Dealings-Sold W. Cushman, on acct., 100 posts@ 21 cts. Paid cash in full of the bank note due yesterday. (No interest.)

E. P. Johnson's report:

Labor-6 hr. self and team delivering merchandise, 4 hr. in dairy.

Product--28 gal. milk.

Dealings-Sold for cash 2 tons timothy hay@ @ $\$ 9$.

Jonas Overburg's report:

Labor $-4 \mathrm{hr}$. self and team delivering merchandise, $\mathrm{I} / 2 \mathrm{hr}$. in dairy, $2 \mathrm{hr}$. in care of teams, $1 \mathrm{r} / 2 \mathrm{hr}$. in care of poultry.

Product-30 eggs gathered.

Dealings-Sold milk tickets (20 gal.) for cash $\$ 5$.

\section{JANUARY 17}

E. A. Atkinson is sick. (Make pencil memo in his ledger account.)

E. P. Johnson's report:

Labor- 6 hr. self and team 2 hr. and 3 horse team 4 hr. getting wood out from timber. 4 lir. in dairy, $\mathrm{r} / 2 \mathrm{hr}$. in care of hogs.

Prodluct-27 gal. milk, 3 cords wood, 28 posts.

Jonas Overburg's report:

Labor- $8 \mathrm{hr}$. self and team delivering merchandise, $\mathrm{t} / 2 \mathrm{hr}$. in care of poultry, $1 \mathrm{hr}$. in care of teams. 
Product-37 eggs gathered. for cash $\$ 2$.

E. P. Johnson's report:

Labor -4 hr. self and team getting out wood from timber, $2 \mathrm{hr}$. self and team delivering merchandise, 4 hrr. in dairy, $1 / 2$ hr. in care of hogs.

Product-26 gal. milk, 3/4 cord wood.

Dealings-Sold for cash 2 tons timothy hay for $\$ 17.75$. Sold to the Goldleaf Creamery Co.; on acct., 16 lb. butter fat@25 cts.

Jonas Overburg's report:

Labor $-5 \mathrm{hr}$. self and team delivering merchandise, $1 \mathrm{r} / 2 \mathrm{hr}$. in care of poultry, $2 \mathrm{hr}$. in care of teams.

Product-26 eggs gathered.

Dealings-Sold 1 cord wood for cash $\$ 5.50$. Sold to A. A. Wells, on acct., 20 doz. eggs@29 cts., milk tickets (12 gal.) for cash $\$ 3$.

\section{E. P. Johnson's report:}

\section{JANUARY 19}

Labor- $-6 \mathrm{hr}$. self and team delivering merchandise, $4 \mathrm{hr}$. in dairy, $\mathrm{r} / 2 \mathrm{hr}$. in care of hogs.

Product-27 gal. milk.

Dealings-Sold 2 tons timothy hay for cash $\$ 17.25$.

Jonas Overburg's report:

Labor -6 hr. self and 2 teams delivering merchandise, $3 \frac{1}{2}$ hr. in care of poultry, 2 hr. in care of teams.

Product-26 eggs gathered. cash $\$ 3$.

Dealings-Sold $1 \frac{1}{4}$ tons timothy hay for cash $\$ 10$. Sold milk tickets (12 gal.) for

E. P. Johnson's report:

\section{JANUARY 20}

Labor $-6 \mathrm{hr}$. repairing fences, $4 \mathrm{hr}$. in dairy, $\mathrm{x} / 2 \mathrm{hr}$. in care of hogs.

Product-26 gal. milk. ground.

Dealings-Sold to A. A. Wells \& Co., on acct., 21/2 tons timothy hay @ $\$ 8.50$ on the Jonas Overburg's report:

Labor- $81 / 2 \mathrm{hr}$. self and team delivering merchandise, $\mathrm{I} / 2 \mathrm{hr}$. in care of poultry, $2 \mathrm{hr}$. in care of teams.

Product-27 eggs gathered.

Dealings-Sold to James Goodwin, on acct., 100 bu.corn@ 99 c. Sold milk tickets (8 gal.) for cash $\$ 2$.

E. P. Johnson's report:

\section{JANUARY 21}

Labor-4 hr. self and team delivering merchandise, $4 \mathrm{hr}$. in dairy, $\mathrm{t} / 2 \mathrm{hr}$. in care of hogs.

Product-24 gal. milk.

Dealings-Sold 3 tons timothy hay for cash \$26. Sold the Goldleaf Creamery Co., on acct., 26 lb. butter fat @26 cts.

Jonas Overburg's report:

Labor- $4 \mathrm{hr}$. self and team delivering merchandise, $4 \mathrm{hr}$. in care of poultry, $2 \mathrm{hr}$. in care of teams.

Product-29 eggs gathered.

Dealings-Sold Mrs. Jane Cramer, on acct., milk tickets (4 gal.) \$1. Sold milk tickets (28 gal.) for cash $\$ 7$.

Enter the week's reports as before.

E. P. Johnson's report:

JANUARY 22

Labor $-4 \mathrm{~T} / 2 \mathrm{hr}$. in dairy.

Product-25 gal. milk. 


\section{Ionas Overburg's report:}

Labor $-5 \mathrm{hr}$. self and team delivering merchandise, $1 \mathrm{hr}$. in care of hogs, $1 \mathrm{r} / 2 \mathrm{hr}$. in care of poultry, $2 \mathrm{hr}$. in care of teams.

Product-27 eggs gathered.

Dealings-Bought of A. Gregory, on acct., 10 gal. milk@16 cts. Sold milk tickets (28 gal.) for cash $\$ 7$.

\section{E. P. Johnson's report:}

\section{JANUARY 23}

Labor $-8 \mathrm{hr}$. self and team delivering merchandise, $4 \mathrm{r} / 2 \mathrm{hr}$. in dairy.

Product-25 gal. milk.

Dealings-Sold for cash 2 cords wood for $\$ 12.40$.

Jonas Overburg's report:

Labor $-5 \mathrm{hr}$. self and team delivering merchandise, $1 \mathrm{hr}$. in care of hogs, $1 / 2 \mathrm{hr}$. in care of poultry, $3 \mathrm{hr}$. in care of teams, $4 \mathrm{hr}$. for Mr. Atkinson personally (charge to Atkinson's personal account through labor summary at close of month.)

Product-28 eggs gathered.

Dealings-Sold A. A. Wells \& Co., on acct., 8 doz. eggs@30 cts. Sold milk tickets (32 gal.) for cash \$8. Bought of A. Gregory, on acct. 8 gal. milk@16 cts.

\section{E. P. Johnson's report:}

\section{JANUARY 24}

Labor-7 hr. self and team delivering merchandise, $5 \mathrm{hr}$. in dairy.

Product-26 gal. milk.

Dealings-Sold A. A.Wells \& Co., on acct., 62 bu. oats@ @ 36 cts., 45 bu. potatoes@ 49 cts.

Jonas Overburg's report:

Labor- 3 hr. self and team getting out wood from timber, 5 hr. self and team delivering merchandise, $1 \mathrm{hr}$. in care of hogs, $1 / 2 \mathrm{hr}$. in care of poultry, $1 \mathrm{r} / 2 \mathrm{hr}$. in care of teams.

Product-31 posts, 27 eggs gathered.

Dealings-Bought of A. Gregory, on acct., 12 gal. milk@16 cts. Sold Mrs. Jane Cramer, on acct., milk tickets (4 gal.) \$1. Sold Eagle Hotel Co., on acct., 10 gal. milk@ 22 cts. Sold milk tickets (20 gal.) for cash $\$ 5$.

\section{E. P. Johnson's report:}

\section{JANUARY 25}

Labor $-7 \mathrm{hr}$. self and team delivering merchandise, $4 \mathrm{~T} / 2 \mathrm{hr}$. in dairy.

Product-25 gal. milk.

Dealings-Sold $1 \frac{1}{4}$ tons prairie hay for cash @ \$5.25. Sold to A. A. Wells \& Co., on acct., 61 bu. turnips@30 cts.

Jonas Overburg's report:

Labor $-2 \frac{1}{2} \mathrm{hr}$. chopping wood in timber, $5 \mathrm{hr}$. self and team delivering merchandise, $1 / 2 \mathrm{hr}$. in care of hogs, $1 \mathrm{hr}$. in care of poultry, $1 \mathrm{r} / 2 \mathrm{hr}$. in care of teams.

Product-23 eggs gathered.

Dealings-Bought of A. Gregory, on acct., 8 gal. milk@16 cts. Sold milk tickets (32 gal.) for cash $\$ 8$.

\section{E. P. Johnson's report:}

\section{JANUARY 26}

Labor $-61 / 2 \mathrm{hr}$. self and team delivering merchandise, $5 \mathrm{hr}$. in dairy.

Product-26 gal. milk.

Dealings-Sold W. Cushman, on acct., 100 posts @ 21 cts.

Jonas Overburg's report:

Labor $-41 / 2 \mathrm{hr}$. self and team delivering merchandise, $\mathrm{r} / 2 \mathrm{hr}$. in care of hogs, $2 \mathrm{hr}$. in care of poultry, $11 / 2 \mathrm{hr}$. in care of teams, $2 \mathrm{hr}$. work for Mr. Atkinson.

Product-26 eggs gathered.

Dealings_Bought of A. Gregory, on acct., 10 gal. milk@16 cts. Sold Eagle Hotel Co., on acct., 10 gal. milk@ 22 cts. Sold milk tickets (16 gal.) for cash $\$ 4$.

\section{E. P. Johnson's report:}

\section{JANUARY 27}

Labor $-7 \mathrm{hr}$. self and team delivering merchandise. $4 \mathrm{I} / 2 \mathrm{hr}$. in dairy. 
Product-26 gal. milk.

Dealings-Sold for cash 87 bu. wheat@96 cts. Paid cash for repairs on wagon $\$ 3.50$. Jonas Overburg's report:

Labor- $5 \mathrm{hr}$. self and team delivering merchandise, $1 \mathrm{hr}$. in care of hogs, $1 \mathrm{hr}$. in care of poultry, $1 \mathrm{hr}$. in care of teams, $2 \mathrm{hr}$. work for Mr. Atkinson.

Product-29 eggs gathered.

Dealings-Sold Goldleaf Creamery Co., on acct., 15 lb. butter fat @ 26 cts.

\section{E. P. Johnson's report:}

\section{JANUARY 28}

Labor $-7 \mathrm{hr}$. self and team delivering merchandise, $4 \mathrm{I} / 2 \mathrm{hr}$. in dairy.

Product-25 gal. milk.

Dealings-Sold for cash 98 bu. corn@ 57 cts. Paid Dr. Burrows cash $\$ 25$ for Mr. Atkinson's account.

Jonas Overburg's report:

Labor- $6 \mathrm{hr}$. self and team delivering merchandise, $1 / 2 \mathrm{hr}$. in care of hogs, $1 \mathrm{r} / 2 \mathrm{hr}$. in care of poultry, $1 \frac{1}{2} \mathrm{hr}$. in care of teams, $1 \mathrm{hr}$. work for Mr. Atkinson.

Product-24 eggs gathered.

Dealings-Sold milk tickets (16 gal.) for cash $\$ 4$.

Enter the week's report as before. Note that the charges for labor for E. A. Atkinson, personal, may be made through the summary book, as there is no haste in posting this account. Write his name at top of the next unused column in summary book and carry charges as in other columns.

The work for the three remaining days of the month will now be taken up, after which the month's summaries will be journalized and posted, and a trial balance will be taken. Note that Johnson and Overburg carry out some unusual transactions which the student should take time to enter correctly.

\section{E. P. Johnson's report:}

\section{JANUARY 29}

Labor-5 hr. in dairy.

Product-26 gal. milk.

Jonas Overburg's report:

Labor $-5 \mathrm{hr}$. self and team delivering merchandise, $1 \mathrm{hr}$. in care of hogs, $1 \mathrm{r} / 2 \mathrm{hr}$. in care of poultry, $2 \mathrm{hr}$. in care of teams.

Product-19 eggs gathered.

\section{E. P. Johnson's report:}

\section{JANUARY 30} Atkinson.

Labor $-7 \mathrm{hr}$. self and team delivering merchandise, $4 \mathrm{r} / 2 \mathrm{hr}$. in dairy, $1 \mathrm{hr}$. work for $\mathrm{Mr}$.

Prodiuct-24 gallons milk.

Dealings-Sold for cash 2 cords wood for $\$ 12.75$, kept out cash $\$ 5$ on account, paid from cash collected for wood $\$ 2$ to drug store for items for $\mathrm{Mr}$. Atkinson.

Jonas Overburg's report:

Labor- $6 \mathrm{hr}$. self and team and $2 \mathrm{hr}$. use of one extra horse in delivering merchandise, $1 \mathrm{hr}$. in care of hogs, 1 hr. in care of poultry, $2 \mathrm{hr}$. in care of teams.

Product-18 eggs gathered.

Dealings-Sold milk tickets (16 gal.) for cash \$4. Sold Eagle Hotel Co., on acct., 12 gal. Milk@22 cts. Sold E. A. Atkinson, on acct., milk tickets (16 gal.)@16 cts per gal. In reporting cash with his ticket, Overburg could produce only $\$ 2.95$; charge him with the shortage.

E. P. Johnson's report:

\section{JANUARY 31}

Labor- $5 \mathrm{hr}$. self and team delivering merchandise, $4 \mathrm{I} / 2 \mathrm{hr}$. in dairy.

Product-23 gal. milk.

Dealings-Took 20 bu. wheat to mill (estimated at market price, 96 cts. per bu.) and brought back $227 \mathrm{lb}$. bran and shorts (charge to Merchandise at $\$ 1.20$ per cwt.) and $455 \mathrm{lb}$. flour (charge to E. A. Atkinson, personal, for the difference between the market value of the 
wheat and the value of the feed taken out.) Bought of A. A. Wells \& Co. on Atkinson's account 1 pair of gloves at 80 cts., for Johnson's personal use.

Jonas Overburg's report:

Labor- 5 hr. self and team delivering merchandise, $\mathrm{r} / 2 \mathrm{hr}$. in care of hogs, $1 \mathrm{hr}$. in care of poultry, 2 hr. in care of teams, $1 \mathrm{r} / 2 \mathrm{hr}$. work for Mr. Atkinson.

Product-22 eggs gathered.

Dealings-Sold Mrs. Jane Cramer, on acct., milk tickets (4 gal.) \$1. Sold milk tickets (32 gal. @ 25 cts.) for cash and reports cash $\$ 6.75$. Sold Goldleaf Creamery Co., on acct., 18 lb. butter fat@27 cts.

Enter last three days, which close the month, on the same plan as the preceding weekly reports.

\section{CLOSING THE MONTH}

Cash: Mr. Atkinson, who is assumed to have charge of the cash, finds that the stub of his bank check book shows that his cash balance in the bank is $\$ 495.67$ and he has cash in pocket $\$ 61.19$, making total cash $\$$ The cash carried over from last month (see trial balance book), plus the debit cash footing of the current month, less the credit cash footing equals \$ showing the actual cash on hand short \$ Charge the shortage to E. A. Atkinson's personal account and credit cash.

Products: From the products summary compute the totals of the different columns at farm prices: Milk at 16 cts. per gal., Eggs at 26 cts. per doz., Wood at $\$ 5$ per cord, Posts at 18 cts. each, Hogs at $\$ 7.55$ per cwt. Charge their total to Mdse. (general column) and credit the respective accounts affected; i. e., Real Estate, Dairy, Hogs, and Poultry. (In charging and crediting departments from the summaries, enter the titles in the order of the ledger accounts for convenience in posting. See model.)

Feed: E. P. Johnson turns in feed ticket for the month which reads as follows:

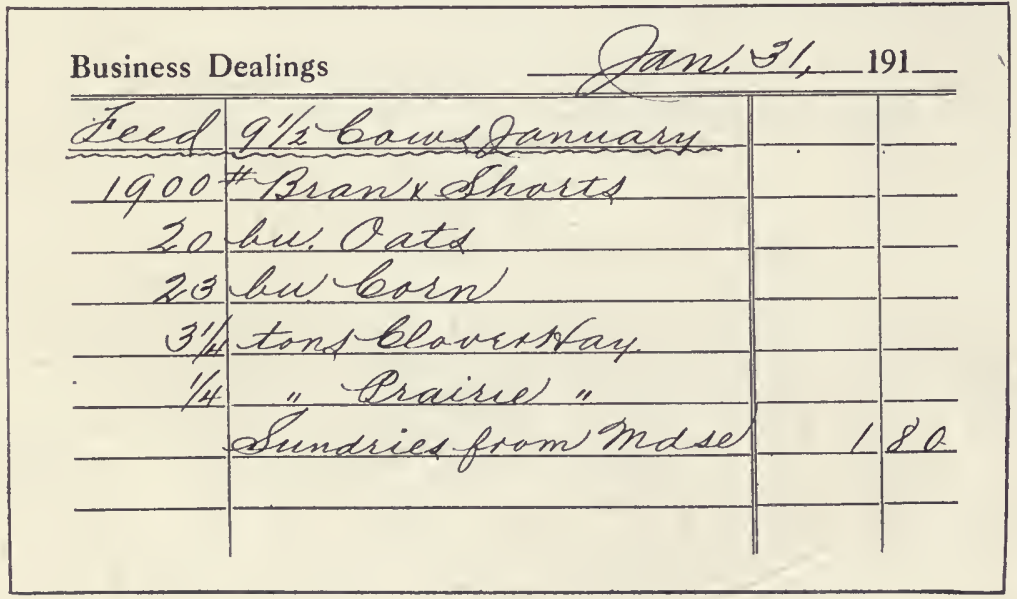

Estimate the feed used at inventory prices.

Overburg turns in a feed ticket as follows:

Feed for horses for month: Timothy hay 3100 lbs., Prairie hay $1 / 2$ ton, corn 25 bu., oats 35 bu. Sundries from mdse. $\$ 3$.

Feed of Poultry charged with inventory No. 38 in full.

Mr. Atkinson makes out the following ticket:

Feed of Chattels for month: Prairie hay $1 \frac{1}{4}$ tons, Clover $1 / 3$ ton, Corn 20 bu., Oats 10 bu. Feed of hogs for month: Corn 65 bu., Oats 30 bu., skim milk 330 gal. at 5 cts.

Journalize as in model.

Labor Charge: Atkinson also makes a ticket crediting E. A. Atkinson $\mathrm{x} / 2$ month wages, Johnson full month and Jonas Overburg full month at the prices agreed upon which are (or should be) noted in their ledger accounts. On the same ticket he enters a memo, "Labor acct. Dr. to E. A. Atkinson, Personal, board Johnson and Overburg 1 month \$30."

Labor Distribution: Foot the labor summary and charge each department according to headings crediting Labor with entire amount as in model. 


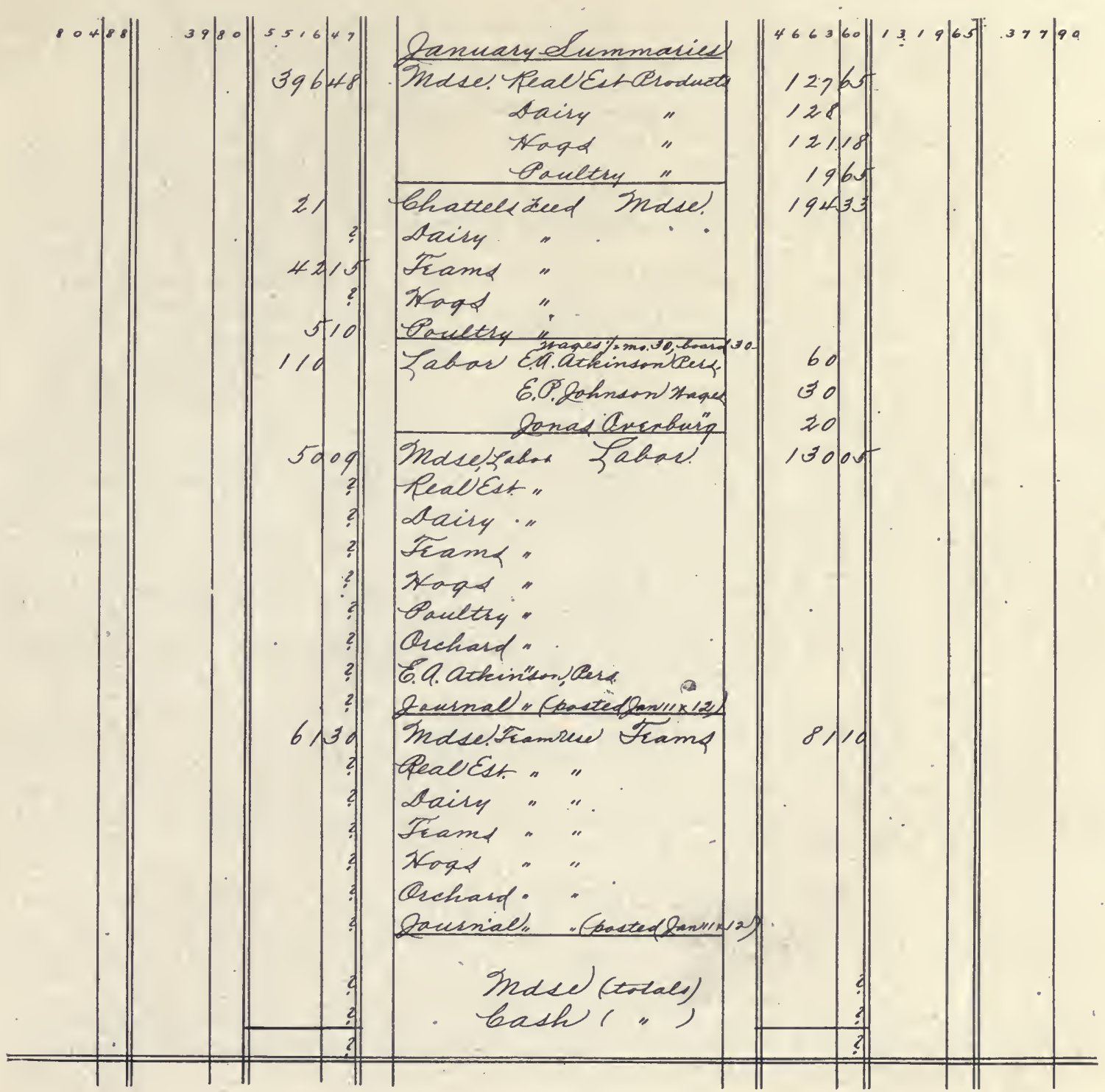

Note the Miscellaneous columm which has a charge to Orchard 18 cts., two items amounting to $\$ 3.60$ which charge to "Journal," (because previously credited in journal without posting). Credit the total to Labor.

Team Use Distribution: Foot the team use simmary and charge each department according to headings crediting Teams with the total as in summary. Items in the miscellaneous column should be journalized. See model.

Closing the Journal: - Carry the special columns (Merchandise and Cash) into the general columns and foot the general columns to show in balance.

Post the ledger. Pencil-foot the ledger, and take a trial balance, recording it in the pair of columns following the one recorded Jan. 1.

\section{SALES SUMMARY (AUXILIARY)}

For purposes of comparison, turn to the sales summary and write in the headings, if they are not already printed, the names of the following products which constitute the principal sales of the month: Corn, Oats, Wheat, Timothy, Milk, Butter, Wood, Posts, Eggs, Potatoes, and Miscellaneous: From the cards enter the quantity and selling amount of each item, and foot in pencil or red ink. This will give an exhibit of the direction of sales during the month and will afford a valuable reference for next January. Also the products on hand 
can be found by adding to inventory Jan. 1, the amount produced and subtracting the amount sold thus: Inventory Jan. 1, 20 cords wood plus January product $17 \mathrm{r} / 4$ cords, less January sales 29 cords, equals $81 / 4$ cords that should be on hand.

With your ledger before you, answer the following questions:

1. Cash account-How much cash was received during the month? How much paid?

2. Merchandise account-What was the cost of delivering the products sold during the month? What was the farm value of the month's production? How much of the farm production was used again for feed? How much was sold?

3. Real Estate account-What was the value of labor and team use put into real estate during the month? What was the salable product? Is this account likely to be as active as here shown during the remainder of the year. What is the $6 \%$ rental value of the real property devoted to department uses? Is all real property now used in departments? What part is not?

4. Chattels account-How much money is now invested in unclassified animals or other personal property?

5. Dairy account - Is there a. profit or loss shown in dairy during the month? How many cows are there? What was the value of the labor on clairy for January? Of feed? Is the product computed at farm price or market price? Why?

6. Teams account-What was the cost of care and feed during the month? What did their use amount to at 20 cents per hour?

7. Orchard account-Was any investment made in orchard during the month? How much?

8. Hogs account-How much labor and feed were expended on hogs during month?

9. Poultry account-Does the ledger show a profit in the poultry department?

10. Labor account-Was the time actually reported in labor greater than expected? How much? If expectations were exactly met, this account would balance out without gain or loss.

11. Among the financial accounts, how do we stand witli Wells \& Co.? How much has Mr. Atkinson been charged with during the month? Some accounts should be collected and some accounts should be paid. Name them.

\section{FEBRUARY}

REMARK.-The card system of records has been demonstrated in the January business. To avoid tiresome repetition, the cards and stmmary books need not be written in the following work, which has been expanded to cover one year's time in order to jllustrate the farm turnover. The value of the cards in checking up time and keeping every one busy, as well as providing vouchers for all charges and entries, has been well demonstrated in factories in general and should not be neglected on the farm. The following memoranda which include monthly summaries is to be entered in the journal direct. It is assumed that the report cards have been used, although they are not to be prepared by the student.

Feb. 1. E. A. Atkinson returns to work. (Ledger memo.) Egg product of January in excess of sales should be charged to E. A. Atkinson, personal,@24 cts.per dozen. (Make journal entry.)

Received from Goldleaf Creamery Co. check to balance account. (Journal entry.)

Collected cash of the Eagle Hotel Co. in full of account.

Paid A. Gregory our check to balance account.

Paid E. P. Johnson our check on account $\$ 15$.

Paid Jonas Overburg our' check to balance January wage credit.

Daily reports are assumed to have been rendered by Atkinson, Johnson, and Overburg, giving the labor and product matter in addition to above transactions. Consicler these tickets entered in Labor, Team Use, and Product Summaries.

Post and rule up accounts that are in balance.

Feb. 2. Bought of W. Cushman, on acct., a bill of lumber, brick, ete., for general repairs on buildings and fences $\$ 49.16$. (Charge Real Estate.) Sold milk tickets (12 gal.) for cash $\$ 3$.

Feb. 3. Sold W. Cushman; on acct., 50 posts@ 21 cts. Sold for cash 2 cords wood @ \$5.75.

Feb. 4. Sold Goldleaf Creamery Co., on acct., 16 lb. butter fat @ 26 cts. Sold milk tickets (16 gal.) for cash $\$ 4$. 
Feb. 6. Jonas Overburg takes a vacation without pay awaiting the opening of spring work. Gave him check for $1 / 6$ month's wages in full. Sold A. A. Wells \& Co., on acct., 5 doz. eggs@26 cts. Sold milk tickets (8 gal.) for cash $\$ 2$.

Feb. 7. Bought for cash 17 hd. shoats for $\$ 102$.

Feb. 8. Sold Eagle Hotel Co., on acct., 17 chickens, 81 1b. @ 11 1/2 cts. Sold for cash 4 cd.wood@\$5.50.

Feb. 9. Sold A. A. Wells \& Co., on acet., 80 bu. potatoes@ 55 cts. Bought of A. A. IVells \& Co. sundry items of stock food per bill $\$ 9.60$. (Charge Mdse.) Sold milk tickets (16 gal.) for cash $\$ 1$.

Feb. 10. Paid cash $\$ 27$ for $\$ 3000$ insurance on buildings, running five years. (Charge Real Estate.) Sold milk tickets (20 gal.) for cash $\$ 5$.

Feb. 11. Sold Goldleaf Creamery Co., on acct., 40 lb. butter fat @26 cts. Sold for cash 2 cd. wood@\$5.25. Bought bill of furniture for E. A. Atkinson, personal, paying for same by check, $\$ 16.27$.

Paid Dr. C. Williams by check, for veterinary surgical attendance on work horse $\$ 9.50$. Sold milk tickets (20 gal.) for cash $\$ 5$. Bought for cash $2000 \mathrm{lb}$. mill feed for $\$ 20$.

Feb. 13. Bought a work horse, "Jim" for $\$ 120$, trading in exchange the horse "Joe" and paying check for the difference $\$ 40$. Soll milk tickets (60 gal.) for cash $\$ 15$.

Feb. 14. Bought of A. A. Wells \& Co., on acct., a bill of goods for E. A. Atkinson's personal use \$40.69. Sold A. A. Wells \& Co., on acct., 15 doz. eggs@ 25 cts. Sold Goldleaf Creamery Co., on acct., 40 lb. butter fat@2t cts.

Feb. 15. Bought for E. P. Johnson's personal use, sundry items $\$ 3.96$, paid by check.

Feb. 16. Sold Eagle Hotel Co., 12 gal. milk@22 cts., on acct.

Feb. 17. Sold for cash 3 hogs, 800 lb.,@ $\$ 7.50$. Bought of A. Gregory, on acct., 15 gal.milk@16 cts.

Feb. 20. Boarded Herbert Jones, a nursery agent, 4 weeks for $\$ 15$, on acct. Jones is to make payment in fruit trees later on. Sold milk tickets (68 gal.) for cash $\$ 17$.

Feb. 25. Sold Goldleaf Creamery Co., on acct.,35 lb. butter fat@24 cts. Sold A. A. Vells \& Co.. on account, 12 doz.eggs@25 cts.

Feb. 27. Sold milk tickets (208 gal.) for cash \$52. Received of Mrs. Jane Cramer cash on acct. $\$ 2$.

.Feb. 28. Sold for cash 4 tons timothy hay @ \$8.50. Sold Goldleaf Creamery Co., on acct., 20 lb. butter fat@24 cts. Charge E.A. Atkinson, Personal, with 18 doz. eggs@ 25 .cts.

\section{SUMMARIES FEBRUARY 28}

The summary tickets and books (assumed to lave been kept as in January) give the following totals:

Products: Milk764 gal. @16 cts.,Eggs629@25 cts.per doz.,Wood 22 cords@ \$4.50, Posts $160 @ 18$ cts., Hogs 800 1b.@\$7.30, Chickens 81 lb.@11 cts. (Charge Mdse. and credit departments.)

ChattclsFeed: 1 ton prairie hay@\$4, t/3 ton clover@\$7.50,15 bu.corn@50 cts., 10 bu. oats@35 cts.

Dairy Feed: 2100 1b.mill feed@\$1.05 per cuvt., 24 bu. oats@35 cts.,20 bu. corn @ 50 cts., 3 ton clover@\$7.50, sundry feed $\$ 2.30$.

Team Feed: Timothy2500 1b.@\$8 per ton, 1 ton prairie hay@\$4,22 bu. corn@ 50 cts., 20 bu. oats@35 cts., sundries \$2.50.

HogFeed: 60 bu.corn@50 cts.,30 bu..oats@35 cts.,20 bu.potatoes@30 cts., 319 gal.skim milk@5 cts.

PoultryFecd: 3 bu.corn@50 cts.,3 bu. oats@35 cts.,12 1rd. cabbage@ 5 cts., 1 bu. potatoes@30 cts.

Labor Charge: Wages Atkinson 1 mo. \$60; Johnsonn 1 mo. \$30; Overburg $1 / 61110$. \$3.33. Board Johnson \$15, Overburg \$3.

Labor Distribution: Mdse. $\$ 24.50$, Real Estate $\$ 20.70$, Dairy $\$ 33.80$, Teanns $\$ 15.68$, Hogs $\$ 8.94$, Poultry $\$ 5.22$.

Team Use Distribution: Mdse. \$42.30, Real Estate \$12.60.

Journalize, post, and take a trial balance. 


\section{MARCH}

Mar. 1. The division of farm land for the year follows: Charge the titles given with the rental at $6 \%$ on valuation of $\$ 100$ per acre and any other debits noted below :

Small Fruit, rental on 1 acre $\$ 6$ and shrubbery worth $\$ 30$; Garden, 2 acres; Potato Crop 5 acres; 2 nd year Timothy Crop, 10 acres, 1 st year Clover; 11 acres; Corn Crop, 40 acres; Oats Crop, 40 acres; Wheat Crop, 15 acres.

Note that 1 acre home ground and 1 acre orchard have alreadly been charged. The 34 acres remaining consist of woodland and pasture and will not be taken out of the Real Estate account.

Enter the above eight appropriations in the journal crediting Real Estate with the total and post to the ledger in the order named, pages 11 to 18 .

Nore.-Small sales of butter, eggs, poultry and the like, which will occur at intervals in the future, will be entered in the sales summary sheets first and totaled from the summary to the journal monthly. See note on Sales Summary, page 5.

Mar. 2. Sold to the Sindlinger Dairy Company the six cows numbered in the inventory $9,11,12,13,14$, and 15 , for $\$ 290$, together with the good will of the milk route which is estimated to be worth the unused milk tickets in customers' hands.

Received checks from Goldleaf Creamery Co. and Eagle Hotel Co. to balance their accounts. Paid A. Gregory check to balance account.

Mar.3. Sold Jonas Overburg, on account, 160 posts@20 cts. (farm price). Sold to W. Cushman, on account, 10 cords wood@\$5.

Mar. 11. Sold for cash 6 hogs, 1300 lb.@\$7.

Mar. 18. There is on hand on this date among other items, the following merchandise: 1153 bu. corn, 346 bu. oats, 9 tons clover, 14 tons timothy, 9 cords wood, 88 posts, 255 bu. potatoes, 59 bu. turnips.

From estimates, it appears that there will be needed to carry through the season 600 bu. corn, all oats on hand, 5 tons clover hay, all timothy, 50 bu. potatoes.

Sold all clover hay in excess of requirements for cash at $\$ 7.90$ per ton.

Mar. 20. Sold W. Cushman, on acct., all wood at $\$ 5.50$ per cord and all posts on hand at 21 cts. each.

Mar. 22. Sold all potatoes in excess of requirements to A. A. Wells \& Co. on account (a) 57 cts. per bu.

Sold all corn in excess of requirements for cash.@ 53 cts. per bu.

Mar. 29. Sold all turnips on hand to A. A. Wells \& Co., on acct., @ 40 cts.

Mar. 30. Paid cash for invoice of seed $\$ 67.90$. (Charge Mdse.)

Mar. 31. Sold for cash, during the month, per sales summary, dairy products $\$ \$ 4.60$, and poultry products $\$ 7$.

There was used for seed 20 bu. wheat@\$1.50,120 bu. oats @ 40 cts., and 23/4 bu. clover@\$8. (Charge departments and credit Mdse. in general column.)

During the month 62 posts were used at farm price, $18 \mathrm{cts}$. each, for repairs of fences. (Charge Real Estate.)

Paid taxes on Real Estate $\$ 109.27$; and on personal property $\$ 25.08$, divided as follows: Merchandise \$13.11, Chattels, \$1.22, Dairy \$2.80, Teams $\$ 6.27$, Hogs $\$ 1.68$.

The appreciable manure distribution for the winter season is as follows: Barn yard manure 63 tons@\$2 (credit Dairy); stable.manure 42 tons@\$2.20 (credit Teams); hog manure 58 tons@\$2.25 (credit Hogs); Poultry manure 3 tons@ @4.50 (credit Poultry). Charge all farm manure to Real Estate.

REMARK.-The student is now in position to note the three distinct interests of which the farmer must keep account if he properly analyzes his farm organization.

(1) The land interest, or the investment in the real estate, necessary to carry on the farm processes. Investment in land is reasonably free from ordinary business risk. If it produces the equivalent of prevailing interest rates on safe investments, the results are satisfactory. This return consists of the credits from the rental charged to crops (or to tenants if rented to others), and from the miscellaneous returns from unclassified portions of the real estate illustrated by wood and pasturage. These credits are diminished by the cost of maintenance including repairs, insurance, taxes, common fertilizer, etc.

(2) The manufacturing interest, which involves the outlays including rental of the land and the returns from producing farm merchandise.

(3) The trading interest, involving the disposition of the merchandise either by selling it or turning it again into production. The attendant expenses of storage, preparation for sale, and delivery are placed against the profit of market prices when sold over farm prices when produced.

A scheme of accounting to be a reliable guide must separate these three interests, and consider the cost and profits of each as apart from the others. 


\section{SUMMARIES MARCH 31} $\$ 6.90$.

Products: 340 gal.milk@16 cts.,507 eggs@20 cts.per doz.,6.hogs, 1320 1b.@

ChattelsFecd: 1 ton prairie hay@\$4, 1/3 ton clover@\$7.50,15 bu.corn@ 50 cts., 10 bu. oats@35 cts.

Dairy Feed: 800 1b.mill feed@\$1.05,10 bu. oats@35 cts.,12 bu.corn@50 cts., $11 / 3$ ton clover@\$7.50, sundry feed@\$1.50.

Team Feed: 1 ton timothy@\$8,1/2 ton prairie@\$4,24 bu.corn@50 cts., 30 bu. oats@35 cts., sundry feed $\$ 1.50$.

HogFeed: 30 bu.corn@50 cts.,20 bu.oats@35 cts.,310 gal.skim milk@5 cts., 10 bu.potatoes@30 cts.

Poultry Feed: 3 bu.corn@50 cts.,3 bu. oats@35 cts., 12 hd. cabbage@ 5 cts.,2 bu. potatoes@30 cts.

Labor Charge: E. A. Atkinson, personal, wages $\$ 60$, board of help $\$ 15$; E. P. Johnson wages $\$ 30$.

Labor Distribution: Mdse. $\$ 16.60$, Real Estate $\$ 22.20$, Dairy $\$ 12.10$, Teams $\$ 16.80$, Hogs \$7.81, Poultry \$5.69, Clover Crop \$4, Oats Crop $\$ 29.50$, Wheat Crop $\$ 6.50$.

Tcam Use Distribution: Mdse. \$17.80, Real Estate \$33.49, 1st year Clover Crop \$7, Oats Crop \$42.80, Wheat Crop \$8.40.

Journalize, post and take trial balance.

\section{QUESTIONS}

1. How much is the cash balance?

2. What is the value of feed used in March?.

3. Name five items other than labor or team use that have been charged to Real Estate account. the year?

4. Is the tendency of Real Estate account'toward an exhibit of $5 \%$ profit at the end of

5. How does the product of dairy for March compare with that for February?

6. Why are field crops charged with ground rent?

7. What three distinct interests are involved in owning and operating a farm?

8. Why are the gains from the use of Real Estate placed at a moderate figure?

9. What accounts are used to represent the operations in farm production?

10. How is the Merchandise account used?

\section{APRIL}

Apr. 1. Jonas Overburg returns to work. He is to receive $\$ 25$ per month and board from this date. (Ledger memo.)

Boùght for cash a bill of special fertilizer for garden \$31.70. (Special fertilizer should be charged to the department to which it is applied.)

\section{SUMMARIES APRIL 30}

Merchandise Sales: Dairy and poultry products have been sold to E. A. Atkinson, personal, on acct., $\$ 8.70$; for cash $\$ 22.40$. (Credit Mdse.)

REMARK.-The student will note that through the spring and summer season the sales will be numerous but small, as it is planned to deliver dairy and poultry products, garden truck and small fruit. Hence it is more convenient to enter the detailed description of sales in the sales summary book, rather than the journal. A report of totals is journalized at the end of the month when cash receipts are entered as one item.

Products: Dairy $\$ 32.40$, Poultry $\$ 9.89$.

Seed: Used for Garden amounting to \$7.30, for Potato Crop 85 bu. potatoes@ @ 80 cts, for Corn Crop61/2 bu. corn@ @1. (Credit Mdse.)

Feed: Chattels $\$ 15.80$, Dairy $\$ 24.50$, Teams $\$ 39.18$, Hogs $\$ 56.80$, Poultry $\$ 3.90$. (Credit Mdse.)

Labor Charge: E. A. Atkinson wages $\$ 60$ and board of hands $\$ 30, \mathrm{E}$. P. Johnson wages $\$ 30$, Jonas Overburg wages $\$ 25$.

Labor Distribution: Mdse. \$4.80, Real Estate \$8.32. Chattels \$1.30, Dairy \$13.50, Teams $\$ 15.60$, Hogs $\$ 8.10$, Poultry $\$ 2.30$, Orchard $\$ 3$, Small Fruit $\$ 6.20$, Gảrden $\$ 19$, Potato Crop $\$ 8$, Corn Crop $\$ 33.40$. 
Tcam Use: Mdse. \$6.20, Orchard \$1, Small Fruit $\$ 2$, Garden $\$ 3.50$, Potato Crop $\$ 5.50$, Corn Crop $\$ 61.20$.

Journalize, post and take trial balance.

Questions from Trial Balance. What is indicated by the fact that Poultry balance has passed-from the debit to the credit side? What is indicated by the Labor balance? How much has been invested in each of the general crops? Why is the Merchandise balance reduced to so small an amount?

\section{MAY}

REMINDER. - The headings in the summary books should be filled in by the bookkeeper to suit the titles to which distribution is made in a given month. For example, during May, sales will be made of dairy, poultry, and garden stuff. These should be represented by suitable columins in the sales summary. It is impossible to print headings in these books to suit all accounts on all farms or on the same farm at different seasons of the year. As these matters were fully explained in the January work, the student will not be required to repeat the process here.

May 1. Herbert Jones delivered for credit on his account small fruit stock amounting to $\$ 9.80$ and special fertilizer for small fruit $\$ 10$, orchard $\$ 5.20$. (Charge departments.)

May 2. Paid cash for telephone service $\$ 12$, for record books and stationery $\$ 2.50$, for subscription to farm paper $\$ 2$, for repair outfit $\$ 9.20$, for lubricator $\$ 3$. (Charge General Expense. Open an account with General Expense and Interest on page 20.)

General Expense and Interest are usually given separate ledger titles in a mercantile business where these accounts are likely to be active. In the present business the transactions involving these titles will seldom occur, and for convenience in ledger and trial balance the titles will be combined.

\section{SUMMARIES MAY 31}

Merchandise Sales: For cash $\$ 42.60$, E. A. Atkinson's acct., $\$ 13.75$.

Products: Dairy $\$ 29.40$, Poultry $\$ 8.39$, Garden Truck $\$ 16.20$.

Seed Used: Garden $\$ 2.35$, Corn Crop $\$ 2.10$.

Feed: Chattels $\$ 15.80$, Dairy $\$ 24.50$, Teams $\$ 39.18$, Hogs $\$ 56.80$, Poultry $\$ 3.90$. (Of this amount $\$ 18$ is for pasturage to be credited to Real Estate. The remainder credits to Merchandise.)

Labor Charge: E. A. Atkinson wages $\$ 60$ and board of help $\$ 30$, E. P. Johnson wages $\$ 30$, Jonas Overburg wages $\$ 25$.

Labor Distribution: Mdse. \$1.35, Real Estate \$12.89, Chattels \$2.50, Dairy \$10.50, Teams \$16.30, Hogs \$9.95, Poultry \$2.15, Orchard \$2.50, Small Fruit \$7.58, Garden \$9.55, Potato Crop $\$ 8.30$, Corn Crop $\$ 22.50$.

Team Use Distribution: Mdse. \$2.10, Real Estate \$4.40, Orchard \$2, Small Fruit \$4, Garden Truck \$4.50, Potato Crop \$5.50, Corn Crop $\$ 32.80$.

Journalize, post and take trial balance.

\section{JUNE}

June 1. Jonas Overburg discontinued work yesterday. evening. He will call to settle his account later.

June 5. Bought of A. A. Wells \& Co., on account, for E. A. Atkinson, personal, merchandise per bill $\$ 69.89$.

\section{SUMMARIES JUNE 30}

Merchandise Sales: Hogs, dairy, poultry, small fruit and garden produce, as per sales summary, $\$ 379.32$ for cash with exception of $\$ 28.90$ to E. A. Atkinson, on personal acct.

Products: Dairy $\$ 24.90,20$ Hogs 4725 1b. $\$ 283.50$, Poultry $\$ 10.60$, Small Fruit $\$ 8.38$, Garden $\$ 46.93$.

Feed: Chattels $\$ 6.95$, Dairy $\$ 20.19$, Teams $\$ 36.20$, Hogs $\$ 49.15$, Poultry $\$ 2.29$. (Credit all to Mdse. except pasture of 22 animals at $\$ 1$ each to be credited to Real Estate.)

Labor Charge: E. A. Atkinson wages $\$ 60$ and board of help $\$ 15$, E. P. Johnson wages $\$ 30$, cash paid for work in garden $\$ 30$.

Labor Distribution: Mdse. \$10.30, Real Estate \$4.60, Chattels \$2.54, Dairy \$9.57, Teams $\$ 18.68$, Hogs $\$ 6.40$, Poultry $\$ 2$, Orchard $\$ 2$, Small Fruit $\$ 4.40$, Garden $\$ 38.71$, Potato Crop $\$ 7.50$, Corn Crop $\$ 21.60$.

Team Use Distribution: Mdse. \$15.26, Orchard \$4, Small Fruit \$1.40, Garden \$6.50, Potato Crop $\$ 3$, Corn Crop $\$ 28.76$.

Journalize, post and take trial balance. 


\section{JULY}

July 1. Paid the semi-annual interest $\$ 175$ on farm loan. (Chảrge Interest and post same to the account with General Expense and Interest.)

Gave Jonas Overburg a check to balance account.

Received cash from Mrs. Jane Cramer in full of account.

Received cash from W. Cushman in full of account.

\section{SUMMARIES JULY 31}

Merchandise Sales: Milk, butter, eggs, fruit and garden truck liave been sold for $\$ 239.80$, from which cash was received for all except $\$ 21.70$ on E. A. Atkinson's account.

- Products: Dairy \$20.16, Poultry \$4.20, Orchard \$1.40, Small. Fruit \$19.82, Garden \$174.38, Timothy 18 tons@6, Clover11 tons@\$6.

Feed: Chattels \$17.83, Dairy \$16.56, Teams \$31.50, Hogs \$26.50, Poultry \$2.15. (Credit Mdse. with all except $\$ 22$ pasturage.)

Labor Charge: E. A. Atkinson wages $\$ 50$, board help $\$ 15$, E. P. Jolnnson wages $\$ 30$, sundry cash payments $\$ 28.50$.

Labor Distribution: Mrlse. \$16.80, Real Estate $\$ 1.25$, Chattels $\$ 3.20$, Dairy $\$ 10.24$, Teams $\$ 15.20$, Hogs $\$ 7.25$, Poultry $\$ 3.20$, Orchard $\$ 3.60$, Small Fruit $\$ 6.30$, Garclen $\$ 34.20$, Potato Crop $\$ 8$, Timothy Crop $\$ 10.70$, Clover Crop $\$ 9.44$, Corn Crop $\$ 6.20$.

Team Use Distribution: Mdse. \$24.60, Garden \$4, Potato Crop \$6, Timothy Crop $\$ 8.90$, Clover Crop $\$ 6.66$, Corn Crop $\$ 9.45$.

Journalize, post and take trial balance.

\section{AUGUST}

Aug. 10. Bought of A. A. Wells \& Co., on acct., 260 lb. binding tivine@10 cts.per lb., (200 lb. for oats crop and $60 \mathrm{lb}$. for wheat crop. Make entry charging the two accounts named.)

\section{SUMMARIES AUGUST 31}

Merchandise Sales: For cash $\$ 179.97$, acct. E. A. Atkinson $\$ 30.69$.

Products: Dairy $\$ 27.60$, Poultry $\$ 3.70$, Orchard $\$ 6.75$, Small Fruit $\$ 49.60$, Garden Truck, \$105.29, 2400 bu. oats@30 cts. and 40 tons oat straw at $\$ 1$ per ton, to be left on the ground for roughage and manure, 300 bu. wheat@90 cts. and 15 tons wheat straw at 75 cts. per ton, left on the ground as above. (Charge straw to Real Estate.)

Fied: Chattels \$21.28, Dairy \$15.80, Teams \$26.59, Hogs \$27.31, Poultry \$2.10. (Pasture \$26, remainder Mdse.)

Labor Charge: E. A. Atkinson wages $\$ 60$, board Johnson, threshing crew and other help $\$ 34.50$, E. P. Johnson wages $\$ 30$. Paid sundry help cash $\$ 8.50$ and threshing bill $\$ 41.40$.

Labor Distribution: .Mdse. \$14.29, Chattels \$3.88, Dairy \$11.50, Hogs \$6.84, Poultry $\$ 1.48$, Teams $\$ 17.39$, Orchard $\$ 1.25$, Small Fruit $\$ 12.80$, Garden $\$ 21.48$, Oats Crop (harvesting, threshing and storing) $\$ 66$, Wheat Crop (harvesting, threshing and storing) $\$ 17.45$.

Team Use Distribution: Mdse. \$19.38, Garden \$3.50, Oats Crop (harvesting, threshing and storing) \$31, Wheat Crop (harvesting, threshing and storing) $\$ 10.70$.

Journalize, post and take trial balance.

\section{SUMMARIES SEPTEMBER 30}

Merchandise Sales: This includes 6 hogs, 200 bu. potatoes, garden truck, dairy and poultry products $\$ 378.60$ for cash with exception of $\$ 26.40$ to $\mathrm{E}$. A. Atkinson on account.

Products: Dairy $\$ 34.60,6$ Hogs 1100 1b. $\$ 71.50$, Poultry $\$ 5.90$, Orchard $\$ 1.90$, Garden Truck \$209.10, 1500 bu. Potatoes@35 cts.

Feed: Chattels \$21.28, Dairy \$15.80, Teams \$26.59, Hogs \$27.31, Poultry \$2.10. (Mdse. except $\$ 26$ pasturage and roughage.)

Labor Chargc: E. A. Atkinson wages $\$ 60$, and board of help $\$ 23.40$; E. P. Johnson wages $\$ 30$; cash for sundry help $\$ 18.60$.

Labor Distribution: Chattels \$4.69, Mdse. \$14.30, Dairy \$9.50, Teams \$18.50, Hogs $\$ 7.32$, Poultry $\$ 1.48$, Orchard $\$ 4.20$, Garden $\$ 10.70$, Potato Crop $\$ 61.80$. 
Tcam Use Distribution: Mdse. \$21.60, Garden \$1.50, Potato Crop \$31.

Journalize, post and take trial balance.

\section{SUMMARIES OCTOBER 31}

Merchandise Sales: $\$ 228.90$ (cash $\$ 168.50$, E. A. Atkinson's acct., the remainder.)

Products: Dairy $\$ 35.30$, Poultry $\$ 10.49$, Garden Truck $\$ 16.20,600$ bu. corn @ 40 cts.

Fecd: Chattels $\$ 20.66$, Dairy $\$ 19.44$, Teams $\$ 32.58$, Hogs $\$ 23.51$, Poultry $\$ 4.20$, (Mdse. except $\$ 21$ pasturage and roughage.)

Labor Charge: E. A. Atkinson wages $2 / 3$ month $\$ 10$ and boaird help $\$ 15, \mathrm{E}$. P. Johnson wages $\$ 30$.

Labor Distribution: Mdse. $\$ 12.50$, Real Estate $\$ 14.30$, Chattels $\$ 5.20$, Dairy $\$ 10.20$. Teams $\$ 12.50$, Hogs $\$ 8.31$, Poultry $\$ 3.25$, Orchard $\$ 36$ cts., Cotn Crop $\$ 18$.

Team Use Distribution: Mdse. $\$ 16.60$, Corn Crop $\$ 20$.

Journalize, post and take trial balance.

\section{SUMMARIES NOVEMBER 30}

Merchandise Sales: $\$ 181.60$ (cash $\$ 157.90$, E. A. Atkinson's acct. charged with remainder.)

Products: Dairy $\$ 36.70$, Poultry $\$ 13.70,1600$ bu. corn @ 40 cts., and 40 acres stalks @ 75 cts. left on ground.

Feed: Chattels \$20.81, Dairy \$20.19, Teans \$37.27, Hogs \$25.60, Poultry \$4.20. (All Mdse. except $\$ 16$ roughage.)

Labor Charge: E. A. Atkinson wages $\$ 60$, board help $\$ 15$; E. P. Johnson wages $\$ 30$.

Labor Distribution: Mdse. \$8, Chattels, \$6.25, Dairy $\$ 12.30$, Teams $\$ 12.80$, Hogs $\$ 9.15$, Poultry $\$ 6.21$, Corn Crop $\$ 48$.

Team Use Distribution: Mdse. $\$ 10.20$, Corn Crop $\$ 53.30$.

Journalize, post and take.trial balance.

\section{DECEMBER}

Dec. 30. Paid the semi-annual interest on loan due Jan. 1.

\section{SUMMARIES DECEMBER 31}

Merchandise Sales: $\$ 78.10$ (cash $\$ 52.20$, E. A. Atkinson remainder..)

Products: Dairy $\$ 38.30$, Poultry $\$ 18.40$.

Feed: Chattels $\$ 21.60$, Dairy $\$ 21.14$, Teams $\$ 30.62$, Hogs $\$ 26.40$, Poultry $\$ 4.70$. (Of this $\$ 12$ is roughage.) $\$ 30$.

Labor Charge: E. A. Atkinson bill for board of Johnson \$15, E. P. Johnson wages

Labor Distribution: Mdse. \$3, Chattels \$6.25, Dairy \$12.30, Teams \$12.50, Hogs $\$ 8.40$, Poultry $\$ 6.21$.

Team Use Distribution: Mdse. \$4.

Journalize, post and take trial balance.

\section{STATEMENT OF THE BUSINESS}

It is now desirable to make a general statement of the business, so arranged as to show resources and liabilities, and losses and gains of the year. The first step is to take an Inventory of property on hand like the one recorded Jan. 1, of this year. The student can make the required statement from the data given below.

Merchandise-There is on hand the following: 15 tons timothy hay @ $\$ 6,10$ tons clover hay@\$6,2000 bu.corn@40 cts.,2300 bu. oats@30 cts.,370 bu. wheat@90 cts., making a total value of $\$ 1973$.

Real Estate-The various outlays for the maintainance of the real estate have kept the soil and buildings unimpaired in value. Hence, items Nos. 1 to 7 of the first inventory will be re-entered at the valuation $\$ 20736.50$.

Chattels - The unclassified animals have increased in number and value being now worth $\$ 600$. 


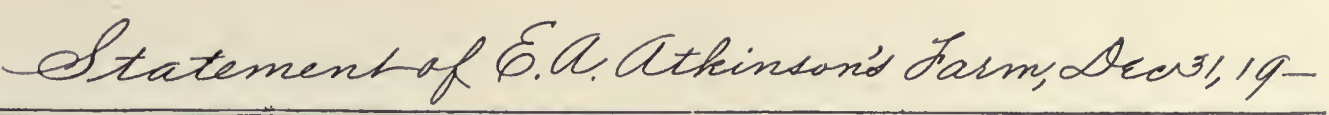

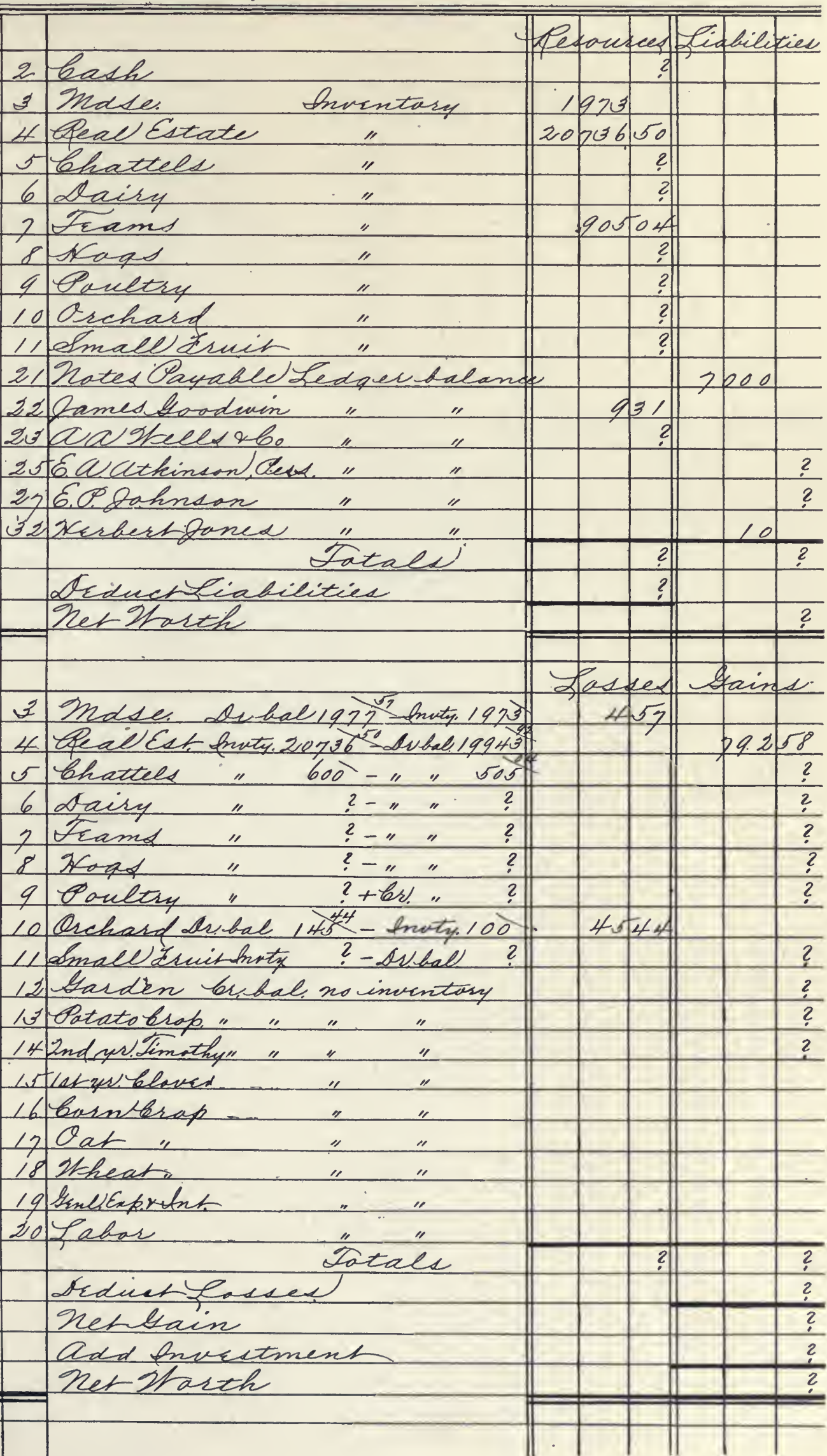


Dairy-Four cows remaining inventoried at the beginning of the year Nos. 8, 10, 16 , and one purchased on Jan. 14 for $\$ 39.50$, amount all told to $\$ 184.50$ less $5 \%$ average depreciation, or $\$ 175.27$. Items Nos. 19 and 20 of first inventory less $12 \%$ depreciation equal $\$ 88$. Total Dairy inventory \$263.27.

Teams-Five horses Nos. 21, 22, 23, and 25, and one bought Feb. 13, were charged at $\$ 680$. They are now considered to have depreciated in value $10 \%$ being now worth $\$ 612$. Machinery Nos. 27 to 35 inventoried Jan. 1, last, at $\$ 333$ have depreciated in value $12 \%$ being now worth $\$ 293.04$. This gives a total teams inventory of $\$ 905.04$.

Hogs-There are now on hand 60 head, $6000 \mathrm{lb}$. worth $\$ 5.50$ per cwt., or $\$ 330$.

Poultry-On hand worth $\$ 18.20$.

Orchard-Stock of trees growing worth $\$ 100$.

Small Fruit-Stock of shrubbery growing worth $\$ 60$.

After completing the statement of resources and liabilities with difference showing net worth, make a detailed list of loss and gain accounts showing net gain. Also show this gain added to investment at opening giving present worth to agree with the amount shown in the financial statement above.

\section{CLOSING THE BOOKS}

Enter the inventories to the credit of their respective accounts in the ledger (red ink), close the accounts on pages 3 to 20 into Loss and Gain (open Loss and Gain account on lower half of page 20) and close Loss and Gain account into proprietor's account. Balance the proprietor's account, carry down inventories and take a trial balance under date of January 1 .

Remark-The person who has carefully watched the accounts of his farm through the period of one year is in position to see the relative gains and losses of different kinds of farm industry. He should now compare his results with the results of others as given in the records of agricultural experiment stations, the information contained in the best agricultural papers, and results obtained by other farmers in his own locality working under similar conditions. However, conditions are so diverse that he must in the main look to his own books rather than to the records of others for his best guidance. A careful record of cost and production, kept through a period of years, will certainly pay many times over for the time and attention given to it.

To this should be added the knowledge of the worth of the business as a business, and the observance of the appreciation or depreciation of real and personal property. These facts tend toward suitable bargains being made in case of purchase or sale. They also tend toward a conservation and an average increase of the general values about him which in the current language of the day are termed-his worth.

\section{PUBLISHERS' NOTICE}

The publishers of Farm Accounting have in stock bound and loose leaf blank books in sizes suited to the requirements of farm bookkeeping. For description and prices, inquire of the school where this course is taught, or write to 
RETURN TO the circulation desk of any

- University of California Library

$$
\text { or to the }
$$

NORTHERN REGIONAL LIBRARY FACILITY

BIdg. 400, Richmond Field Station

University of California

Richmond, CA 94804-4698

ALL BOOKS MAY BE RECALLED AFTER 7 DAYS

2 -month loans may be renewed by calling (415) 642-6233

1 -year loans may be recharged by bringing books to NRLF

Renewals and recharges may be made 4 days prior to due date

DUE AS STAMPED BELOW

\section{APR 91989}




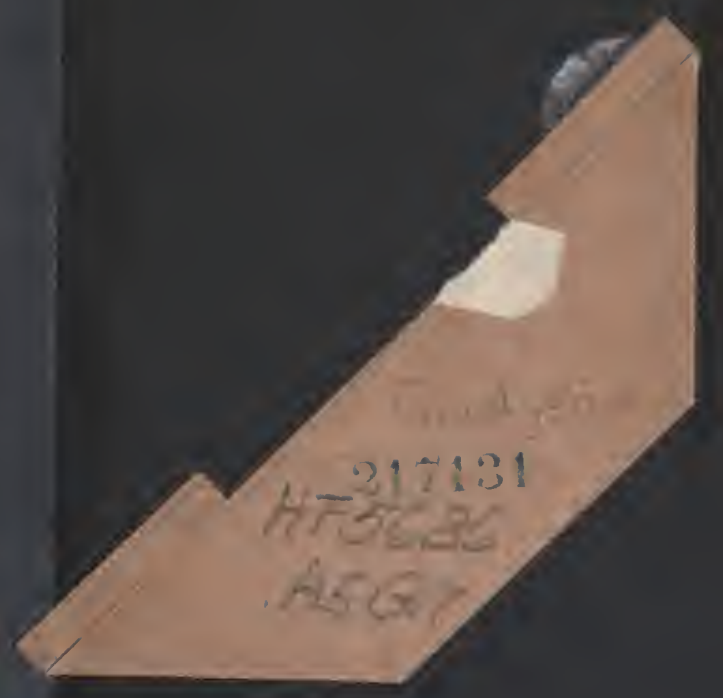


